\title{
Adaptive Immune Responses in Human Atherosclerosis
}

\author{
Silvia Lee ${ }^{1,2, *}$, Benjamin Bartlett ${ }^{1,3}$ and Girish Dwivedi ${ }^{1,3,4}$ \\ 1 Department of Advanced Clinical and Translational Cardiovascular Imaging, Harry Perkins Institute of \\ Medical Research, Murdoch 6150, Australia; benjamin.bartlett@research.uwa.edu.au (B.B.); \\ girish.dwivedi@perkins.uwa.edu.au (G.D.) \\ 2 Department of Microbiology, Pathwest Laboratory Medicine, Murdoch 6150, Australia \\ 3 School of Medicine, University of Western Australia, Nedlands 6009, Australia \\ 4 Department of Cardiology, Fiona Stanley Hospital, Murdoch 6150, Australia \\ * Correspondence: silvia.lee@uwa.edu.au; Tel.: +61-8-6151-1261
}

Received: 29 October 2020; Accepted: 2 December 2020; Published: 7 December 2020

\begin{abstract}
Atherosclerosis is a chronic inflammatory disease that is initiated by the deposition and accumulation of low-density lipoproteins in the artery wall. In this review, we will discuss the role of T- and B-cells in human plaques at different stages of atherosclerosis and the utility of profiling circulating immune cells to monitor atherosclerosis progression. Evidence supports a proatherogenic role for intraplaque $\mathrm{T}$ helper type 1 (Th1) cells, $\mathrm{CD} 4{ }^{+} \mathrm{CD} 28^{\text {null }} \mathrm{T}$-cells, and natural killer T-cells, whereas Th2 cells and regulatory T-cells (Treg) have an atheroprotective role. Several studies indicate that intraplaque T-cells are activated upon recognition of endogenous antigens including heat shock protein 60 and oxidized low-density lipoprotein, but antigens derived from pathogens can also trigger T-cell proliferation and cytokine production. Future studies are needed to assess whether circulating cellular biomarkers can improve identification of vulnerable lesions so that effective intervention can be implemented before clinical manifestations are apparent.
\end{abstract}

Keywords: human atherosclerosis; adaptive immune response; T-cells; B-cells

\section{Introduction}

Atherosclerosis is a chronic vascular disease involving endothelial dysfunction following the deposition and accumulation of lipoproteins (e.g., low-density lipoproteins (LDL)) in the arterial intima. Plaque rupture and subsequent arterial occlusion can lead to myocardial infarction and stroke, which are the leading causes of death worldwide. The initiation and progression of atherosclerosis involve inflammatory pathways, with the recruitment and activation of several immune cell types and the release of soluble mediators [1]. Cells of the innate immune system, primarily macrophages, can take up modified oxidized LDL (oxLDL) and transform into foam cells to form fatty streaks ("early plaques") [2]. Further lipid accumulation and leukocyte infiltration into established atherosclerotic plaques ("advanced") create a core region with a collagen-rich fibrous cap established by vascular smooth muscle cells [2]. Plaques can be categorized into two broad categories: stable or unstable. Stable plaques are characterized by a small lipid core, few inflammatory immune cells, and a thick fibrous cap. Unstable (also known as "vulnerable") plaques often have a very large lipid core, a thin fibrous cap, and intraplaque hemorrhage [2].

Cells of the innate and adaptive immune system are present in the different layers (intima, media, and adventitia) of the artery walls throughout the development of atherosclerotic plaques in mice and humans [3,4]. Studies using gene knockout mice have enabled detailed analyses of immune cells involved in atherogenesis [4], whilst human studies are more limited. However, it is important to 
highlight that different genetic and environmental factors affect atherogenesis in mice and humans. It is well established that different subsets of monocytes and macrophages play a crucial role in the atherosclerotic plaque establishment and disease progression [4]. In this review, we will summarize the roles of adaptive immune cells in human atherosclerotic plaques and review the clinical utility of profiling circulating immune cells in this context.

\section{Development of T-Cell Subsets}

Following antigen presentation by antigen-presenting cells (e.g., dendritic cells) and recognition by $\mathrm{T}$-cell receptors, naive $\mathrm{CD} 4^{+}$and $\mathrm{CD} 8^{+} \mathrm{T}$-cells $\left(\mathrm{T}_{\mathrm{N}}\right)$ differentiate into central memory $\left(\mathrm{T}_{\mathrm{CM}}\right)$ or effector memory T-cells $\left(\mathrm{T}_{\mathrm{EM}}\right)$ [5] (Figure $\left.1 \mathrm{~A}\right)$. $\mathrm{T}_{\mathrm{CM}}$ generally reside in lymphoid tissues and are primed for rapid response to a previously encountered antigen. Following activation, $\mathrm{T}_{\mathrm{CM}}$ undergo clonal expansion and differentiate into $\mathrm{T}_{\mathrm{EM}}$. $\mathrm{T}_{\mathrm{EM}}$ can be defined by their expression of the cell surface receptor, CD45RO, and low levels of costimulatory receptors (e.g., CD28). Furthermore, these cells display loss of chemokine receptors (e.g., CCR7) necessary for cells to migrate to secondary lymphoid tissues such as lymph nodes and spleen, whilst there is upregulation of receptors required for migration to peripheral sites of inflammation (e.g., CCR5 and CXCR3). In response to antigens, both $\mathrm{T}_{\mathrm{CM}}$ and $\mathrm{T}_{\mathrm{EM}}$ can produce effector cytokines, but $\mathrm{T}_{\mathrm{CM}}$ possess higher proliferative capacities. Chronic exposure to antigens results in the generation of terminal effector T-cells $\left(\mathrm{T}_{\mathrm{TE}}\right)$ that proliferate poorly but have strong cytokine-producing and cytotoxic capabilities.

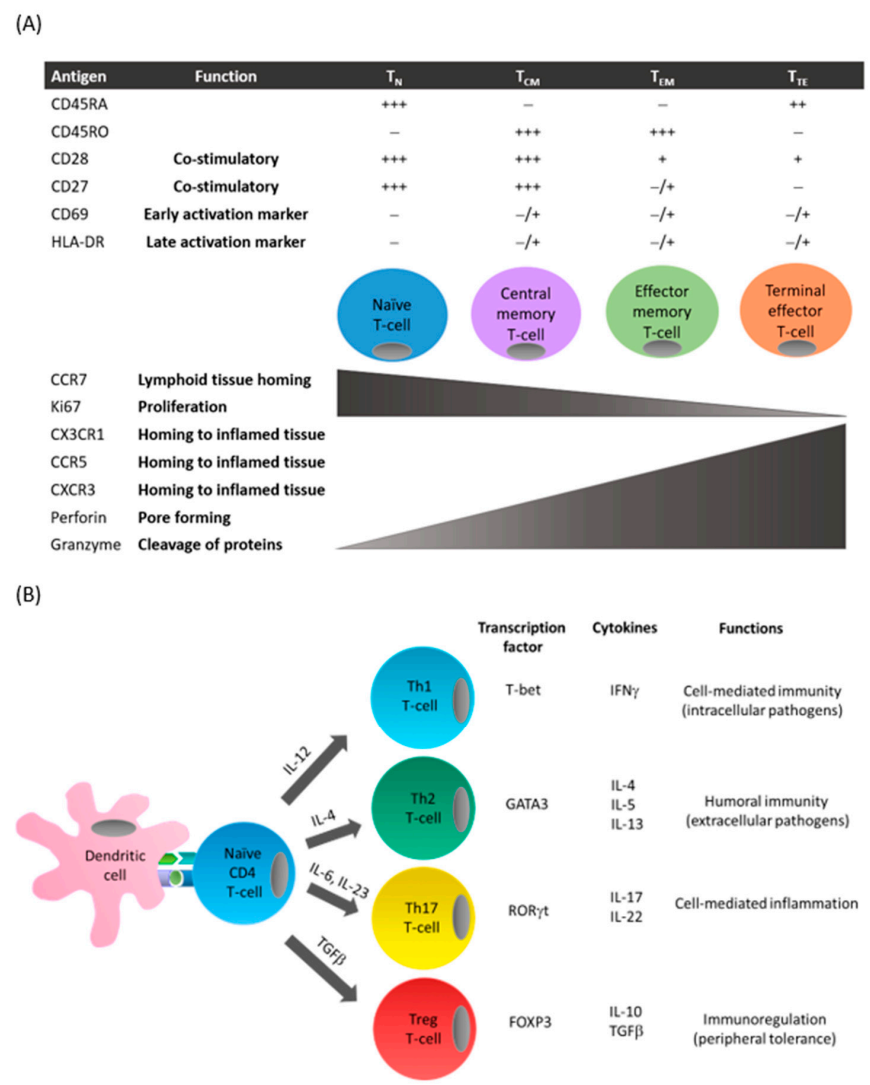

Figure 1. T-cell differentiation. (A) Following antigen presentation by antigen-presenting cells such as dendritic cells, naïve T-cells can differentiate to central memory or effector T-cells. This process is associated with the presence $(+)$ or absence $(-)$ of cell surface receptor expression on T-cells including costimulatory molecules and chemokine receptors, and functions including proliferation and cytotoxicity. (B) Depending on the costimulatory signals and the cytokines produced by antigen-presenting cells in the surrounding microenvironment, $\mathrm{CD} 4{ }^{+} \mathrm{T}$-cells express specific transcription factors that favor the differentiation into the different $\mathrm{T}$-cell subsets. These subsets can be characterized by their distinctive cytokine secretion profile and associated effector functions. 
Depending on the antigen, costimulatory signals, and cytokine milieu of the microenvironment, naïve $\mathrm{CD} 4^{+} \mathrm{T}$-cells differentiate into distinct $\mathrm{T}$ helper (Th) lineages (Figure 1B). T helper 1 (Th1) cells produce predominantly interferon (IFN) $\gamma$, Th2 cells produce interleukin (IL)-4, IL-5, and IL-13, and Th17 cells secrete IL-17 and IL-22 [5]. Differentiation into Th1, Th2, or Th17 subsets is controlled by specific transcription factors: T-bet, GATA3, and ROR $\gamma \mathrm{t}$, respectively. Each Th cell subset possesses a unique expression profile and specific functions during an immune response.

Macrophages play a crucial role in regulating Th1/Th2 immune responses and can be broadly classified into two main subtypes: classically activated M1 macrophages and alternatively activated M2 macrophages [4]. M1 macrophages direct T-cells to produce Th1 cytokines to stimulate cytolytic activity and recruit more M1 macrophages and are considered proinflammatory. In contrast, M2 macrophages stimulate T-cells to produce Th2 cytokines to induce B-cell proliferation and amplify M2 macrophage responses and are considered anti-inflammatory. An imbalance of macrophage M1-M2 polarization can lead to inflammation and disease.

Human regulatory T-cells (Treg) can suppress the activation of immune cells through cell-to-cell contact and/or the secretion of inhibitory cytokines (e.g., transforming growth factor (TGF)- $\beta$ and IL-10) [6]. They are characterized by the expression of the transcription factor forkhead box P3 (FOXP3) and the IL-2 receptor $\alpha$ subunit, CD25.

\section{T-Cells in Atherosclerotic Plaques}

\section{1. $\mathrm{CD}^{+}$T-Cells}

CD3 is a cell surface molecule that associates with the T-cell receptor (TCR) and is critical for the activation of $\mathrm{CD} 4^{+}$and $\mathrm{CD} 8^{+}$T-cells. It is commonly used as a pan T-cell marker in immunostaining protocols. In 1986, Jonasson et al. first demonstrated the presence of $\mathrm{CD}^{+}$T-cells in carotid plaques that were predominately located in the fibrous cap and constituted $20 \%$ of the total infiltrating cells [7]. A study of samples from autopsies revealed large numbers of $\mathrm{CD}^{+} \mathrm{T}$-cells in the intimal and adventitial layers of coronary arteries displaying fatty streaks, with the highest numbers reported in advanced plaques with intimal thickening or necrotic cores [8]. A comprehensive histological study of human aortic tissues encompassing the entire spectrum of atherosclerotic disease confirmed the presence of $\mathrm{CD}^{+} \mathrm{T}$-cells in the intima at all stages of atherosclerosis whereas $\mathrm{CD}^{+} \mathrm{T}$-cells were present only in the medial layer of arteries displaying intimal thickening or in vulnerable plaques [9]. The authors also observed reduced numbers of $\mathrm{CD}^{+} \mathrm{T}$-cells in the intima of healed ruptures and fibrotic calcified plaques [9]. Similarly, Rohm et al. reported higher numbers of $\mathrm{CD}^{+} \mathrm{T}$ cells in unstable plaques compared to stable plaques or vessels with no evidence of atherosclerosis [10].

Initial studies suggested that approximately $5-35 \%$ of $\mathrm{CD}^{+} \mathrm{T}$-cells within plaques were activated and involved in the inflammatory response [11,12]. Immunofluorescent staining demonstrated increased expression of the chemokine CX3CL1 and its receptor CX3CR1 in the fibrous cap of coronary and carotid plaques [13]. The staining colocalized with $\mathrm{CD}^{+} \mathrm{T}$-cells, suggestive of active recruitment of immune cells to inflamed tissues [13].

Previous studies using immunohistochemical or immunofluorescent staining investigated the location of immune cells within the plaque but do not reveal dynamic changes, assess the whole tissue, or provide detailed phenotypes of infiltrating cells. Flow cytometry allows unbiased quantitation and characterization of T-cells in affected tissues. For example, most cells isolated from endarterectomy specimens after collagenase digestion were found to be $\mathrm{CD}^{+} \mathrm{T}$-cells, displayed a memory phenotype, and expressed markers of immune activation (e.g., CD25, HLA-DR) [12,14]. Combining flow cytometry and an ex vivo model of plaques, Lebedeva et al. confirmed the predominance of T-cells within carotid plaques [15]. 


\section{2. $C D 4^{+} T$-Cells}

$\mathrm{CD}^{+} \mathrm{T}$-cells have been shown to be more abundant in unstable plaques compared to stable plaques or arteries with no evidence of atherosclerosis [10]. Van Dijk et al. reported an absence of CD4 ${ }^{+}$T-cells in the intimal and medial layers of early plaques whereas their numbers were increased in late fibrous plaques but then decreased in healed plaque ruptures [9]. CD4 ${ }^{+} \mathrm{T}$-cells with an effector memory or terminally differentiated phenotype have been found to predominate within plaques [16]. Additionally, intraplaque $\mathrm{CD}^{+}$T-cells displayed a more activated profile (i.e., increased HLA-DR expression) [16], suggesting the presence of foreign antigens within plaques. Using mass cytometry and single-cell RNA sequencing analyses, $\mathrm{CD} 4^{+} \mathrm{T}$-cells in atherosclerotic plaques from symptomatic (stroke) patients displayed gene expression profiles consistent with activation, differentiation, and exhaustion whereas $\mathrm{CD} 4^{+}$T-cells were mostly activated in plaques from asymptomatic (no recent stroke) patients [17].

There is compelling evidence pointing to a role for Th1 $\mathrm{CD} 4^{+} \mathrm{T}$-cells in promoting inflammation and atherosclerosis in humans. Using immunohistochemical and polymerase chain reaction techniques, Frostegard et al. demonstrated that Th1 $\mathrm{CD}^{+}{ }^{+} \mathrm{T}$-cells predominated in advanced plaques, whereas Th2 cytokines including IL-4 and IL-5 were rarely detected [18]. Other investigators confirmed the Th1 bias of infiltrating $\mathrm{CD} 4^{+} \mathrm{T}$-cells in aortic or carotid plaques $[19,20]$. Intraplaque $\mathrm{CD} 4^{+} \mathrm{T}$-cells have been shown to express the chemokine receptor CXCR3 and this was associated with expression of IFN $\gamma$-inducible CXC chemokines-IFN-inducible protein 10 (IP-10), monokine induced by IFN $\gamma$ (MIG), and IFN-inducible T-cell $\alpha$ chemoattractant (I-TAC) in endothelial cells, smooth muscle cells, and macrophages within the plaques [21]. This study revealed a role for chemokine signaling through CXCR3 in promoting recruitment and homing of Th1 cells to the site of plaque development. Furthermore, the proinflammatory cytokines IL-12 and IL-18, which act synergistically to promote T-cell differentiation along the Th1 lineage, have been identified in atherosclerotic plaques [22-24]. IFN $\gamma$ is known to activate macrophages and dendritic cells, inhibit proliferation of vascular smooth muscle cells, and reduce production of collagen by these cells, leading to thinning of the fibrous cap and plaque destabilization [25].

Although plaque-infiltrating CD4 ${ }^{+}$T-cells were shown to produce mainly IFN $\gamma$, other studies found some CD4 ${ }^{+}$T-cells produce only IL-17 or both cytokines following polyclonal stimulation $[16,26]$. This may explain the increased plasma levels of IL-17 from patients with acute myocardial infarction or unstable angina compared to patients with stable angina or healthy controls [27-29]. Furthermore, positive associations have been observed between IL-17 levels and severity of carotid artery plaques [30].

A subset of $\mathrm{CD}^{+}$T-cell lacking CD28 expression (representing $5-23 \%$ of all CD4 ${ }^{+} \mathrm{T}$-cells) and producing high levels of IFN $\gamma$ and tumor necrosis factor (TNF) $\alpha$ have been found in the plaques from patients with acute coronary syndrome (ACS) [31,32]. CD28 is a costimulatory receptor necessary for T-cell activation and proliferation, so the loss of CD28 has been suggested to reflect repeated antigenic exposure [33]. $\mathrm{CD} 4{ }^{+} \mathrm{CD} 28^{\text {null }} \mathrm{T}$-cells have been shown to accumulate in unstable ruptured coronary plaque [31], and express high levels of OX40 and 4-1BB costimulatory proteins, which regulate degranulation and release of molecules involved in cytotoxicity including perforin and granzyme $\mathrm{B}$ [32]. These findings suggest that $\mathrm{CD} 4^{+} \mathrm{CD} 28^{\text {null }} \mathrm{T}$-cells may damage cells in the vascular wall, thereby affecting the stability of plaques.

\section{3. $\mathrm{CD} 8^{+} \mathrm{T}$-Cells}

$\mathrm{CD}^{+}$T-cells have been found to be more abundant in unstable plaques compared to stable plaques [10]. CD8 ${ }^{+} \mathrm{T}$-cells in advanced plaques resided mainly in the shoulder region and fibrous cap of the plaques [34]. Van Dijk et al. demonstrated CD8 ${ }^{+}$T-cells in the intimal layer throughout the progression of atherosclerosis, but these cells predominated in the medial layer of advanced unstable plaques and numbers decreased in stable lesions [9]. Plaques were found to be enriched for $\mathrm{CD} 8^{+}$ T-cells that were primarily $\mathrm{T}_{\mathrm{EM}}$ cells, displayed an activated phenotype, and expressed IFN $\gamma$, IL-2, or IL-17 [16]. Likewise, using mass cytometry and single-cell RNA sequencing analyses, Fernandez et al. reported plaque-derived $\mathrm{CD} 8^{+} \mathrm{T}$-cells were predominantly differentiated and activated and displayed 
evidence of clonal expansion [17]. A recent study demonstrated an inverse correlation between percentages of $\mathrm{CD}^{+}$T-cells and macrophages in advanced plaques [35]. As this was not evident with $\mathrm{CD} 4^{+} \mathrm{T}$-cells, the authors inferred that $\mathrm{CD} 8^{+} \mathrm{T}$-cells may play a protective role by reducing macrophage accumulation [35]. Granzyme B has been shown to localize to CD8 ${ }^{+}$T-cells near the necrotic core of advanced plaques with a fibrous cap [36] and may be responsible for the apoptosis of macrophage-derived foam cells [37].

\subsection{Treg Cells}

Frequencies of FOXP3 ${ }^{+}$Treg cells have been shown to be higher in the intima of lipid-rich advanced plaques compared to early lesions [38]. Furthermore, Patel et al. found that increased number of FOXP3 $^{+}$Treg cells and the Treg-associated cytokine IL-10 in carotid plaques were associated with symptomatic disease [39]. However, other investigators evaluating the plaque shoulder, which is prone to infiltrating immune cells, reported lower numbers of Treg cells in unstable plaques that correlated inversely with the number of dendritic cells $[10,40]$. Furthermore, unstable plaques were shown to have reduced mRNA expression of TGF- $\beta$ [40], a Treg cell-associated cytokine that possess atheroprotective roles including suppression of lymphocyte and endothelial cell proliferation [41]. Results from experimental models have also identified several other potential mechanisms by which Treg cells and TGF- $\beta$ production can affect plaque development and stability. These include inhibition of T- and B-cell effector functions, modulation of dendritic cell function and maturation, and inhibition of macrophage inflammation [42,43].

\section{5. $\gamma \delta$ T-Cells}

$\gamma \delta$ T-cells are important innate-like T-cells with a role in inflammation, infectious diseases, tumor surveillance, and autoimmunity. They represent $1-5 \%$ of circulating T-cells in the blood and recognize nonpeptide antigens such as lipids and phosphorylated nucleotides [44]. In apolipoprotein E knockout mice, $\gamma \delta$ T-cells were found to be the major T-cell subset in early aortic root and arch lesions $[45,46]$ and produced predominantly IL-17 [45]. Human studies of $\gamma \delta$ T-cells in atherosclerotic lesions are limited. In humans, $\gamma \delta$ T-cells have been demonstrated in plaques [47,48], with high frequencies observed in the aorta during the early stages (i.e., fatty streaks with infiltration of macrophages and lymphocytes but no foam cells) of atherosclerosis [47]. Further human studies are required to address the precise role of $\gamma \delta$ T-cells in atherosclerosis.

\subsection{NKT Cells}

Natural killer T (NKT) cells are a unique subset of T-cells that express markers of NK and T-cells [49]. They can be classified as type 1 (invariant) or type 2 (CD1d-restricted) NKT cells. Invariant NKT cells express a restricted TCR repertoire comprising a V $\alpha 24-\mathrm{J} \alpha 18 \mathrm{TCR} \alpha$ chain that is preferentially paired with a V $\beta 11$ TCR $\beta$ chain, whereas type 2 NKT cells have more variable TCRs. Invariant NKT cells recognize glycolipid antigens presented by the major histocompatibility complex (MHC) class I-like molecule CD1d expressed on antigen-presenting cells. Using flow cytometry, high percentages of NKT cells were identified in advanced plaques from patients with atherosclerosis [50]. Bobryshev et al. demonstrated NKT cells in the rupture-prone shoulders of advanced plaques that colocalized with CD1d-expressing dendritic cells [51]. Similarly, in plaques from patients with symptomatic atherosclerosis, Kyriakakis et al. revealed that up to 3\% of infiltrating $\mathrm{CD}^{+}$T-cells stained for $\mathrm{V} \beta 11$ or $\mathrm{V} \alpha 24$ and confirmed the colocalization of NKT cells with $\mathrm{CD} 1 \mathrm{~d}^{+}$ cells [52]. Using immunohistochemical staining, an increased number of NKT cells were demonstrated in unstable plaques compared to stable lesions [10]. Plaque-derived NKT cells exhibited high sensitivity to antigen stimulation and also proangiogenic and pro-inflammatory activity, suggesting a role for these cells in plaque neovascularization and destabilization [52]. Furthermore, NKT cells isolated from atherosclerotic plaques in patients with abdominal aortic aneurysm promoted apoptosis of 
vascular smooth muscle cells via Fas, IFN $\gamma$ production, and CD40 signaling which may affect stability of plaques [53].

\section{B-Cells in Atherosclerotic Lesions}

Compared to murine studies, evidence for a role of B-cells in human atherosclerosis is limited. In whole blood gene expression profiles from the Framingham Heart Study, genes associated with B-cell activation were reported to be expressed at higher levels in healthy controls compared to patients with coronary heart disease, suggesting a protective role [54]. However, B-cells have been demonstrated to be rare or undetectable by immunohistochemical staining $[7,11]$ or constituted $<1 \%$ of cells in plaques using flow cytometry [15]. Using polymerase chain reaction (PCR), Hamze et al. demonstrated the presence of IgG- and IgA-expressing B-cells in the arterial wall and showed that they produced proinflammatory cytokines including IL-6, TNF- $\alpha$, and granulocyte-macrophage colony-stimulating factor (GM-CSF) [55].

\section{Activation of T-Cells in Atherosclerotic Plaques}

As mentioned previously, T-cells in atherosclerotic plaques mainly display an activated profile. Analysis of the T-cell repertoire in coronary plaques from patients with ACS or chronic stable angina revealed increased T-cells and specific T-cell clonotype expansions in unstable plaques but not in the peripheral blood, suggesting antigen-driven recruitment of T-cells to unstable plaques [56].

Several studies indicate that intraplaque T-cells are activated upon recognition of endogenous antigens. Heat shock proteins (HSP) are stress proteins that are conserved in prokaryotic and eukaryotic cells. Of these, HSP60 has been extensively studied in human atherosclerosis. Benagiano et al. found that in vivo activated $\mathrm{CD} 4^{+}$(but not $\mathrm{CD} 8^{+}$) T-cells isolated from carotid plaques could be stimulated with human HSP60 to secrete IFN $\gamma$ and TNF $\alpha$ [57]. Plaque-derived T-cells displayed increased reactivity against human HSP60 compared to peripheral blood-derived T-cells from the same individual and exhibited an oligoclonally restricted T-cell receptor repertoire, suggestive of antigen-driven proliferation within the plaque [58]. Furthermore, cocultures of HSP60-stimulated myeloid dendritic cells with T-cells isolated from plaques from the same individual were found to induce T-cell activation [59]. The authors also detected IFN $\gamma$, IL-6, TNF $\alpha$, and IL-17 in myeloid dendritic cell-T-cell coculture supernatants and increased expression of the transcription factors T-bet (Th1) and ROR $\gamma \mathrm{t}$ (Th17) [59].

Production of reactive oxygen species and nitrogen species by endothelial cells mediates LDL oxidation in the vascular wall [60]. Scavenger receptors on macrophages have a high affinity for oxLDL resulting in lipid accumulation and the formation of foam cells. T-cell clones derived from plaques have been shown to become activated upon recognition of oxLDL [61]. Proliferation was observed when T-cells isolated from plaques were cultured with oxLDL-stimulated blood-derived dendritic cells $[62,63]$. This effect was abolished by atorvastatin (lipid-lowering medication) treatment [63] or reduced by inhibition of proprotein convertase subtilisin/kexin type 9 (PCSK9) [62].

Genetic studies have shown that a variant of bactericidal/permeability-increasing fold-containing family B member 4 (BPIFB4), a gene associated with longevity, may confer protection from cardiovascular diseases [64,65]. Mechanistically, Ciaglia et al. demonstrated that BPIFB4 promoted M2 polarization [66] and decreased activation of T-cells [67]. Further studies are warranted to determine whether BPIFB4 can be utilized as a novel therapeutic target in the management of atherosclerosis.

\section{Role of Pathogens in the Pathogenesis of Atherosclerosis}

Several pathogens have been implicated in the increased risk of cardiovascular disease. These pathogens, both bacteria and viruses, can infect several different cell types important in the pathogenesis of atherosclerosis, including monocytes and macrophages. Inflammation induced by these infectious agents may accelerate atherosclerotic plaque progression.

Cytomegalovirus (CMV) is a beta herpesvirus with a seroprevalence of $50-90 \%$ depending on age and geographic and socioeconomic status [68]. The association between CMV seropositivity and 
increased risk of cardiovascular disease is evident in epidemiological studies [69] of immunocompetent individuals, HIV-infected patients [70], and solid-organ transplant recipients [71].

Direct effects of CMV on atherosclerosis have been established in vivo by the detection of the virus in endothelial cells, smooth muscle cells, and monocytes/macrophages. CMV DNA has been identified in $63 \%$ of plaques obtained during coronary artery bypass graft surgery [72]. Compared to tissues with no evidence of atherosclerosis, CMV antigen and DNA were detected more frequently in atherosclerotic plaques from patients [73,74]. However, other investigators reported no differences in the detection of CMV DNA in atherosclerotic plaques compared to healthy vessels $[75,76]$. This may depend on the stage of atherosclerosis as one study identified CMV DNA in fatty streaks and early plaques, but it was rare in advanced plaques [77]. In contrast, another study reported higher CMV DNA and antigen in advanced plaques compared to early plaques [78]. CMV-positive cells were found to be mainly localized in the shoulder regions of the plaques but also in areas adjacent to the necrotic core and in the fibrous cap [79].

Nitiskaya et al. reported that $82 \%$ of plaques obtained from patients who underwent carotid endarterectomy had detectable CMV DNA and levels positively correlated with proportions of infiltrating $\mathrm{T}_{\mathrm{EM}} \mathrm{CD} 4^{+}$and $\mathrm{CD} 8^{+}$T-cells [80]. Similarly, Yaiw et al. demonstrated plaques positive for $\mathrm{CMV}$ had increased infiltration of $\mathrm{CD}^{+}$T-cells [79], suggesting that the virus may be involved in the inflammatory process. Indeed, in vitro studies showed that soluble factors (IFN $\gamma, \mathrm{TNF} \alpha$ ) secreted by CMV-specific T-cells can activate endothelial cells to produce chemokines (IP-10, fractalkine) and adhesion molecules that promote further recruitment of effector $\mathrm{CD} 4^{+}$and $\mathrm{CD} 8^{+} \mathrm{T}$-cells $[81,82]$ and induce apoptosis in activated endothelial cells [81].

Izadi et al. reported an association between the presence of CMV DNA in coronary atherosclerotic plaques with a history of unstable angina and myocardial infarction [83]. Furthermore, detection rate of CMV by immunohistochemistry in coronary plaques was higher in patients with ACS compared to patients with no ACS [84].

Epstein-Barr virus (EBV) is a common pathogen, with more than $90 \%$ of adults infected worldwide. EBV DNA has been detected in 17/30 plaques obtained during coronary artery bypass graft surgery [72]. Another study found EBV-specific cytotoxic T-cells and EBV DNA in 11/19 plaques from patients undergoing carotid endarterectomy [85]. The authors implicated EBV-specific T-cells in plaque inflammation as these cells were found throughout the intimal layer of the arteries, expressed the activation markers CD40L and CD25, and produced IFN $\gamma$ and granzymes [85].

Epidemiological studies and randomized clinical trials have demonstrated an association between influenza infection and cardiovascular disease [86]. Influenza infection increased the risks of ACS and stroke, whereas vaccination against influenza reduced the risk of these major adverse cardiovascular events. Despite the absence of influenza A viral genome in atherosclerotic plaques, plaque-derived T-cells demonstrated high proliferative responses that were virus-specific and mainly involved CD4 ${ }^{+}$T-cells [87].

Chlamydia pneumoniae (C. pneumoniae) is a common pathogen in human respiratory tract infection and several studies have identified the bacteria in unstable plaques taken from patients who underwent carotid endarterectomy $[88,89]$. T-cell lines derived from carotid tissues have been found to proliferate in response to C. pneumoniae antigens, comprise predominantly $\mathrm{CD} 4^{+} \mathrm{T}$-cells, and primarily display a Th1 cytokine profile [88]. Furthermore, the majority of the C. pneumoniae-specific cell lines were shown to be also responsive to HSP60 [88]. Symptomatic carotid plaques positive for C. pneumoniae demonstrated increased $\mathrm{CD}^{+}, \mathrm{CD}^{+}$, and $\mathrm{CD} 45 \mathrm{RO}^{+}$T-cells compared to asymptomatic plaques [90]. However, in symptomatic plaques without C. pneumoniae, CD4 ${ }^{+} \mathrm{T}$-cells and CD45RO ${ }^{+}$memory T-cells were increased, but not $\mathrm{CD} 8^{+} \mathrm{T}$-cells when compared with asymptomatic plaques [90]. 


\section{Clinical Utility of Profiling Circulating Cells of the Adaptive Immune System to Monitor Atherosclerosis}

To date, there are no reliable biomarkers that can predict risk of major adverse cardiovascular events in individuals with subclinical atherosclerosis due to the difficulties in identifying unstable atherosclerotic plaques that are prone to rupture. Similar to noninvasive imaging modalities that are currently used to evaluate atherosclerotic plaque burden and composition, profiling T- and B-cells in blood specimens may provide vital information on disease progression. The development of multicolor flow cytometry technologies has facilitated detailed phenotypic and functional analyses of circulating immune cell subpopulations. Recent studies are summarized in Table 1.

Table 1. Clinical utility of profiling circulating cells of the adaptive immune system to monitor atherosclerosis progression.

\begin{tabular}{|c|c|c|c|}
\hline Immune Cell/s & Patient Group & Findings & Ref \\
\hline $\mathrm{CD} 4^{+} \mathrm{CD} 28^{\text {null }}$ & CAD, Controls & $\begin{array}{l}\uparrow \text { frequencies of } \\
\mathrm{CD} 4{ }^{+} \mathrm{CD} 28^{\text {null }} \mathrm{T} \text {-cells } \\
\text { expressing the CX3CR1 in } \\
\text { patients with CAD compared } \\
\text { to controls }\end{array}$ & [13] \\
\hline CD4 $^{+}$T-cells (Th1, Th17) & $\begin{array}{l}\text { Acute MI }(n=26), \\
\text { UA }(n=16), \text { SA }(n=16), \\
\text { Controls }(n=16)\end{array}$ & $\begin{array}{l}\uparrow \text { frequencies of Th1 and } \\
\text { Th17 CD4 } 4^{+} \text {T-cells in acute } \\
\text { MI and UA patients } \\
\text { compared with SA patients } \\
\text { and healthy controls }\end{array}$ & [29] \\
\hline NKT cells & $\begin{array}{l}\text { Asymptomatic } \\
\text { atherosclerosis patients } \\
(n=10), \text { Symptomatic } \\
\text { atherosclerosis patients } \\
(n=10), \text { Controls }(n=10)\end{array}$ & $\begin{array}{l}\downarrow \text { frequencies of NKT cells in } \\
\text { patients with atherosclerosis, } \\
\text { with the lowest percentages } \\
\text { reported in patients with } \\
\text { symptomatic (defined as } \\
\text { having a previous CV } \\
\text { event) atherosclerosis }\end{array}$ & [52] \\
\hline $\mathrm{CD} 4^{+}$T-cells & $\begin{array}{l}\text { Chronic SAP }(n=30), \\
\text { Acute MI }(n=60), \\
\text { Controls }(n=40)\end{array}$ & $\begin{array}{l}\text { - } \quad \text { frequencies of } \mathrm{T}_{\mathrm{EM}} \text { and } \\
\text { HLA-DR CD4 } 4^{+} \mathrm{T} \text {-cells in } \\
\text { chronic SAP and acute MI } \\
\text { patients compared to controls } \\
\text { Proportions of } \mathrm{T}_{\mathrm{EM}} \text { and } \\
\text { HLA-DR CD4 }{ }^{+} \mathrm{T} \text {-cells were } \\
\text { similar in chronic SAP and } \\
\text { acute MI patients } \\
\text { Percentages of } \mathrm{T}_{\mathrm{EM}} \text { and } \\
\text { HLA-DR CD4 } 4^{+} \mathrm{T}-\mathrm{cells} \\
\text { correlated with IMT }\end{array}$ & [91] \\
\hline
\end{tabular}


Table 1. Cont.

\begin{tabular}{|c|c|c|c|}
\hline Immune Cell/s & Patient Group & Findings & Ref \\
\hline $\begin{array}{l}\mathrm{CD} 4^{+} \text {T-cells, } \mathrm{CD}^{+} \\
\text {T-cells, B-cells }\end{array}$ & $\begin{array}{l}\text { Nonobstructive CAD } \\
(n=21), \operatorname{ACS}(n=52), \\
\text { Controls }(n=50)\end{array}$ & 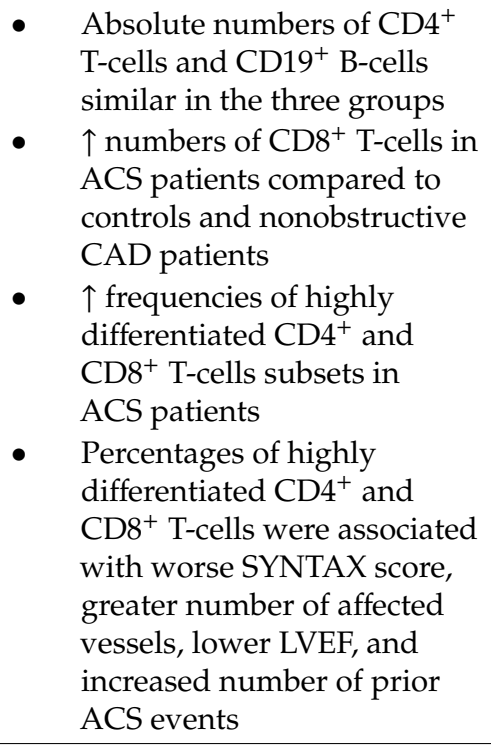 & [92] \\
\hline $\begin{array}{l}\text { CD4 }{ }^{+} \text {T-cells (Th1, Th2, } \\
\text { Th17, Tregs) }\end{array}$ & $\begin{array}{l}\text { Acute MI }(n=19) \\
\text { UA }(n=25), \text { SA }(n=20) \text {, } \\
\text { Controls }(n=24)\end{array}$ & $\begin{array}{l}\uparrow \text { frequencies of Th1 cells in } \\
\text { acute MI and UA patients } \\
\text { compared to SA patients } \\
\text { and controls } \\
\text { Frequencies of Th17 and Th2 } \\
\text { were similar in the } \\
\text { four groups } \\
\downarrow \text { frequencies of Tregs } \\
\left(\mathrm{CD} 25^{+} \text {FOXP3 }{ }^{+}\right) \text {in acute MI } \\
\text { and UA patients compared } \\
\text { with SA patients and controls }\end{array}$ & [93] \\
\hline $\mathrm{CD}^{+}{ }^{+}$T-cells (Th1, Th2) & $\begin{array}{l}\text { Stable CAD }(n=35), \\
\text { STE }(n=30), \\
\text { NSTE }(n=35), \\
\text { Controls }(n=33)\end{array}$ & $\begin{array}{l}\text { - } \quad \text { frequencies of Th1 cells and } \\
\text { Th1/Th2 ratio in STE and } \\
\text { NSTE patients compared to } \\
\text { patients with stable CAD } \\
\text { and controls } \\
\text { Proportions of Th1 T-cells } \\
\text { and Th1/Th2 ratio also } \\
\text { correlated with the number } \\
\text { of affected coronary arteries, } \\
\text { the degree of coronary artery } \\
\text { stenosis, and lengths } \\
\text { of lesions }\end{array}$ & [94] \\
\hline Tregs & $\begin{array}{l}\text { CAD (SAP and previous } \\
\text { MI) }(n=73) \\
\text { Controls }(n=64)\end{array}$ & $\begin{array}{l}\downarrow \quad \downarrow \text { frequencies of Tregs } \\
\left(\mathrm{FOXP}^{+}\right) \text {and } \mathrm{T}_{\text {reg }} / \mathrm{T}_{\text {eff }} \text { ratio } \\
\text { in CAD patients compared } \\
\text { to controls } \\
\text { - } \quad \uparrow \text { expression of activation } \\
\text { markers CD } 25 \text { and CTLA4 } \\
\text { on Tregs from CAD patients } \\
\text { compared to controls } \\
\text { - } \mathrm{T}_{\text {reg }} / \mathrm{T}_{\text {eff }} \text { ratio correlated } \\
\text { inversely with levels of } \\
\text { hs-HRP in CAD patients }\end{array}$ & [95] \\
\hline
\end{tabular}


Table 1. Cont.

\begin{tabular}{|c|c|c|c|}
\hline Immune Cell/s & Patient Group & Findings & Ref \\
\hline $\mathrm{CD}^{+}{ }^{\mathrm{T}}$-cells & $\begin{array}{l}\text { SAP }(n=34), \text { ACS } \\
(n=30), \text { Controls }(n=36)\end{array}$ & $\begin{array}{l}\uparrow \text { numbers and percentages } \\
\text { of CD } 8^{+} \text {CD } 56^{+} \text {T-cells were } \\
\text { higher in ACS and SAP } \\
\text { patients compared to controls }\end{array}$ & [96] \\
\hline $\mathrm{CD}^{+}{ }^{+} \mathrm{T}$-cells & $\begin{array}{l}\text { Subjects with a coronary } \\
\text { event }(n=84), \text { stroke } \\
(n=54) \text {, or no event } \\
(n=549) \text { during the } \\
\text { 15-year follow-up }\end{array}$ & $\begin{array}{l}\text { - High frequencies of CD8 } \\
\text { T-cells at baseline were } \\
\text { associated with increased } \\
\text { incidence of coronary events } \\
\text { but not ischemic stroke } \\
\text { High frequencies of } \\
\text { CD }{ }^{+} \mathrm{CD} 56^{-} \mathrm{T} \text {-cells } \\
\text { producing IFN } \gamma \text { at baseline } \\
\text { were associated with } \\
\text { increased incidence of } \\
\text { ischemic stroke }\end{array}$ & [97] \\
\hline $\mathrm{CD}^{+}{ }^{+}$T-cells & $\begin{array}{l}\text { Stable CAD }(n=66), \\
\text { ACS }(n=34)\end{array}$ & $\begin{array}{l}\downarrow \text { frequencies of } \mathrm{T}_{\mathrm{N}} \text { and } \uparrow \\
\text { frequencies of } \mathrm{T}_{\mathrm{EM}} \mathrm{CD} 8^{+} \\
\text {T-cells in ACS patients } \\
\text { compared to stable } \\
\text { CAD patients }\end{array}$ & [98] \\
\hline $\mathrm{CD}^{+}{ }^{\mathrm{T}}$-cells & $\begin{array}{l}\text { Patients with } \\
\text { nonsignificant lesions } \\
(n=41) \text {, Patients with } \\
\text { severe lesions }(n=37), \\
\text { Controls }(n=36)\end{array}$ & $\begin{array}{l}\downarrow \quad \downarrow \text { frequencies of } \mathrm{T}_{\mathrm{N}} \mathrm{CD} 8^{+} \\
\text {T-cells in patients with severe } \\
\text { lesions than controls } \\
\text { - } \quad \text { Percentages of } \mathrm{T}_{\mathrm{N}} \mathrm{CD} 8^{+} \\
\text {T-cells correlated inversely } \\
\text { with Gensini score } \\
\text { - Proportions of } \mathrm{T}_{\mathrm{N}} \mathrm{CD} 8^{+} \\
\text {T-cells correlated inversely } \\
\text { with PWV in controls but not } \\
\text { in patients } \\
\text { with atherosclerosis }\end{array}$ & [99] \\
\hline Tregs & $\begin{array}{l}\text { Chronic SAP }(n=36), \\
\text { NSTE ACS }(n=50), \\
\text { ST acute MI }(n=39) \\
\text { Controls }(n=75)\end{array}$ & $\begin{array}{l}\downarrow \text { frequencies of Tregs } \\
\left(\mathrm{CD} 25^{\text {high }} \mathrm{CD} 127^{\text {low }}\right) \text { in } \\
\text { non-ST ACS patients and } \uparrow \\
\text { frequencies of Tregs in ST } \\
\text { acute MI patients compared } \\
\text { to chronic SAP patients } \\
\text { and controls }\end{array}$ & [100] \\
\hline Tregs & $\begin{array}{l}\text { ACS }(n=26), \text { Post-ACS } \\
(n=57,24 \text { STE, and } 33 \\
\text { NSTE), Controls }(n=41)\end{array}$ & $\begin{array}{l}\downarrow \text { frequencies of naïve Tregs } \\
\left(\text { FOXP3 } 3^{+} \text {or }\right. \\
\left.\text { CD } 25^{\text {high }} \text { CD } 127^{\text {low }}\right) \text { in ACS } \\
\text { and post-ACS patients } \\
\text { compared with controls } \\
\text { Proportion of naïve Tregs } \\
\text { correlated inversely with the } \\
\text { presence of plaques on the } \\
\text { right and left carotid and also } \\
\text { with right carotid IMT }\end{array}$ & [101] \\
\hline
\end{tabular}


Table 1. Cont.

\begin{tabular}{|c|c|c|c|}
\hline Immune Cell/s & Patient Group & Findings & Ref \\
\hline Tregs & $\begin{array}{l}\text { ACS }(n=48) \\
\text { SAP }(n=24) \\
\text { Controls }(n=24)\end{array}$ & $\begin{array}{l}\text { - } \quad \downarrow \text { frequencies of Tregs } \\
\left(\mathrm{CD} 25^{+} \mathrm{CD} 127^{\text {low }}\right) \text { in ACS } \\
\text { patients compared with SAP } \\
\text { patients and controls } \\
\text { - } \quad \text { Frequencies of Tregs } \\
\text { correlated inversely with } \\
\text { levels of hs-CRP }\end{array}$ & [102] \\
\hline Tregs & $\begin{array}{l}\text { PCI with no disease } \\
\text { progression }(n=32), \\
\text { PCI with new stenosis } \\
(n=24), \text { Patients with } \\
\text { three-vessel coronary } \\
\text { disease }(n=34), \\
\text { No atherosclerosis } \\
(n=27)\end{array}$ & $\begin{array}{l}\downarrow \text { frequencies of Tregs } \\
\text { (FOXP3 }{ }^{+} \text {or } \\
\left.\text { CD25 }{ }^{\text {high }} \text { CD127low }\right) \text { in } \\
\text { patients with multivessel } \\
\text { atherosclerosis compared to } \\
\text { individuals with } \\
\text { no atherosclerosis } \\
\text { Percentages of Tregs were } \\
\text { similar in the three groups } \\
\text { of patients } \\
\text { Frequencies of Tregs } \\
\text { correlated inversely with } \\
\text { Gensini score in patients with } \\
\text { multivessel atherosclerosis }\end{array}$ & [103] \\
\hline Tregs & $\begin{array}{l}\text { SAP }(n=34) \\
\text { ACS }(n=37) \\
\text { Controls }(n=35)\end{array}$ & $\begin{array}{l}\downarrow \quad \downarrow \text { frequencies of Tregs } \\
\left(\mathrm{CD} 25^{+} \mathrm{CD} 127-\right) \text { in ACS } \\
\text { patients compared to SAP } \\
\text { patients and controls } \\
\text { - } \quad \text { Similar percentages of Tregs } \\
\text { in SAP patients and controls }\end{array}$ & [104] \\
\hline $\begin{array}{l}\mathrm{CD}^{+}{ }^{+} \text {T-cells, } \mathrm{CD}^{+} \\
\text {T-cells, B-cells, Tregs }\end{array}$ & $\begin{array}{l}\operatorname{SAP}(n=13) \\
\operatorname{ACS}(n=13)\end{array}$ & $\begin{array}{l}\text { No differences in percentages } \\
\text { of CD } 4^{+} \text {and CD } 8^{+} \text {T-cells, } \\
\text { activated }\left(\mathrm{CD} 69^{+} \text {or }\right. \\
\left.\text { HLA-DR }^{+}\right) \text {T-cells, B-cells, } \\
\text { and Tregs }\left(\mathrm{CD} 25^{+} \text {and/or }\right. \\
\left.\text { FOXP3 }^{+}\right) \text {between SAP and } \\
\text { ACS patients }\end{array}$ & [105] \\
\hline B-cells & $\begin{array}{l}\text { Patients with advanced } \\
\text { atherosclerosis who did } \\
\text { not experience a } \\
\text { secondary CV event } \\
\text { during 3-year follow-up } \\
(n=118) \text { and those who } \\
\text { did }(n=54)\end{array}$ & $\begin{array}{l}\downarrow \text { frequencies of CD19+ } \\
\text { B-cells, unswitched } \\
\text { (expressing IgM) and } \\
\text { switched (expressing IgA or } \\
\text { IgG) memory cells in patients } \\
\text { who experienced a secondary } \\
\text { CVD event compared to } \\
\text { those who did not }\end{array}$ & [106] \\
\hline B-cells & $\begin{array}{l}\text { Individuals }(n=700) \\
\text { with a coronary } \\
\text { event }(n=84) \text {, } \\
\text { stroke }(n=66) \text {, or no } \\
\text { event }(n=549) \text { during } \\
\text { 15-year follow-up }\end{array}$ & $\begin{array}{l}\downarrow \text { proportions of suppressive } \\
\text { CD } 19^{+} \mathrm{CD} 40^{+} \text {B-cells but } \uparrow \\
\text { frequencies of activated } \\
\left(\mathrm{CD} 19^{+} \mathrm{CD} 86^{+}\right) \text {B-cells at } \\
\text { baseline in individuals with } \\
\text { a later incidence of stroke } \\
\text { compared to those with } \\
\text { no event } \\
\text { B-cell subsets were not } \\
\text { associated with increased } \\
\text { risk of CAD }\end{array}$ & [107] \\
\hline
\end{tabular}


Table 1. Cont.

\begin{tabular}{|c|c|c|c|}
\hline Immune Cell/s & Patient Group & Findings & Ref \\
\hline NKT cells & $\begin{array}{l}\text { STE acute MI (PCI and } \\
\text { follow-up) }(n=52)\end{array}$ & $\begin{array}{l}\text { Percentage and absolute } \\
\text { number of NKT cells did not } \\
\text { change during acute MI and } \\
\text { at follow-up }\end{array}$ & [108] \\
\hline
\end{tabular}

Tregs, regulatory T-cells; $\mathrm{T}_{\mathrm{EM}}$, effector memory T-cells; $\mathrm{T}_{\mathrm{N}}$, naïve T-cells; ACS, acute coronary syndrome; LVEF, left ventricular ejection fraction; STE, ST elevation; NSTE, non-ST elevation; IMT, intima-media thickness; SAP, stable angina pectoris; $\mathrm{UA}$, unstable angina; hs-CRP, high-sensitivity $\mathrm{C}$-reactive protein; $\mathrm{CAD}$, coronary artery disease; MI, myocardial infarction; $\mathrm{PCI}$, percutaneous coronary intervention; $\mathrm{CV}$, cardiovascular; $\mathrm{CMV}$, cytomegalovirus; PBMC, peripheral blood mononuclear cells; PWV, pulse wave velocity; $\uparrow$, increased; $\downarrow$, decreased.

\section{1. $C D 4^{+}$T-Cells}

In multiple regression analyses, age, creatinine, and $\mathrm{T}_{\mathrm{EM}} \mathrm{CD} 4^{+} \mathrm{T}$-cells were reported to be independent predictors of carotid intima-media thickness, a noninvasive measure of subclinical atherosclerosis [91]. The authors also observed increased frequencies of $\mathrm{T}_{\mathrm{EM}}$ and activated $\mathrm{CD} 4^{+}$ T-cells in patients with acute myocardial infarction or chronic stable angina compared with controls, whereas no differences were detected for $\mathrm{CD}^{+}{ }^{+}$T-cells expressing the chemokine receptors, CCR5 or CXCR3 [91]. Increased percentages of highly differentiated CD4 ${ }^{+}$T-cells were found in ACS patients compared to patients with nonobstructive coronary artery disease (CAD) and healthy controls. Furthermore, higher degree of $\mathrm{CD} 4^{+}$T-cell differentiation correlated with more diseased vessels, lower left ventricular ejection fraction, increased number of prior ACS events, and worse SYNTAX score, which is an angiographic grading tool to determine the complexity of the CAD [92]. Together, these studies suggest ACS is associated with aging of the adaptive immune system and this correlates with measurements of disease pathology.

In patients with acute myocardial infarction or unstable angina, proportions of Th1 CD4 ${ }^{+} \mathrm{T}$-cells were found to be higher compared to patients with stable angina with no differences observed for frequencies of Th2 and Th17 CD4 ${ }^{+}$T-cells between the two groups [93]. In a recent study, Li et al. reported increased percentages of Th1 $\mathrm{CD} 4^{+} \mathrm{T}$-cells and Th1/Th2 ratio in patients with acute myocardial infarction compared to patients with stable CAD [94]. Proportions of Th1 T-cells and Th1/Th2 ratio also correlated with the number of affected coronary arteries, the degree of coronary artery stenosis, and lengths of lesions [94].

$\mathrm{CD} 4{ }^{+} \mathrm{CD} 28^{\text {null }} \mathrm{T}$-cells have been shown to be increased in individuals with CAD compared to those without CAD [95]. Expression of the chemokine receptor CX3CR1 on CD4 ${ }^{+} C D 28^{\text {null }} T$-cells was also higher in patients with CAD than the control group [13] and this could explain the recruitment and accumulation of these cells within atherosclerotic plaques. Interestingly, CMV infection has been found to drive the accumulation of proatherogenic $\mathrm{CD} 4{ }^{+} \mathrm{CD} 28^{\text {null }} \mathrm{T}$-cells in the circulation and these cells have the ability to recognize CMV antigens [109].

\section{2. $\mathrm{CD} 8^{+}$T-Cells}

Bergstrom et al. reported higher numbers and percentages of $\mathrm{CD} 8^{+} \mathrm{T}$-cells expressing the natural killer cell marker CD56 in ACS and stable angina patients than in healthy controls independent of age, sex, and CMV seropositivity [96]. The authors also demonstrated higher proportions of CD8 ${ }^{+} \mathrm{CD} 56^{+}$ T-cells expressing IFN $\gamma$ compared to $\mathrm{CD} 8{ }^{+} \mathrm{CD} 56^{-} \mathrm{T}$-cells following stimulation, indicating a potential role for these cells in atherosclerosis progression and plaque instability [96]. In another study, Kolbus et al. investigated two subsets of activated CD8 ${ }^{+}$T-cells $\left(\mathrm{CD} 8^{+} \mathrm{CD} 25^{+}\right.$and $\mathrm{CD} 8{ }^{+} \mathrm{CD} 56^{-} \mathrm{T}$-cells expressing IFN $\gamma$ ) as a predictor of acute myocardial infarction and ischemic stroke during 15-year follow-up [97]. They found that high frequencies of $\mathrm{CD}^{+}$T-cells were associated with increased incidence of coronary events but not ischemic stroke after adjustments for other cardiovascular risk factors [97]. Furthermore, proportions of $\mathrm{CD} 8{ }^{+} \mathrm{CD} 25^{+} \mathrm{T}$-cells positively correlated with the degree of stenosis whereas inverse correlations were observed between the percentages of $\mathrm{CD} 8^{+} \mathrm{CD} 56^{-}$ 
T-cells expressing IFN $\gamma$ and the degree of stenosis and carotid intima-media thickness, suggestive of differential roles of $\mathrm{CD}^{+}{ }^{+} \mathrm{T}$-cell populations in disease progression [97].

Frequencies of circulating CD8 ${ }^{+} \mathrm{T}$-cells expressing CXCR3 have been reported to be increased in CAD patients [110]. These effector $\mathrm{CD} 8^{+} \mathrm{T}$-cells can home to inflammatory sites via the chemokine IP-10, MIG, and I-TAC, which are expressed by endothelial cells, smooth muscle cells, and macrophages in human carotid atherosclerotic plaques [25]. Furthermore, production of IFN $\gamma$, perforin, and granzyme $\mathrm{B}$ by CD8 ${ }^{+} \mathrm{T}$-cells can contribute to plaque rupture by promoting apoptosis of cells within lesions [111].

Percentages of $\mathrm{T}_{\mathrm{EM}} \mathrm{CD} 8^{+} \mathrm{T}$-cells have been found to be increased in ACS patients compared to stable CAD patients [98] and in patients with CAD compared to healthy controls [112]. Detailed analyses of $\mathrm{T}_{\mathrm{EM}} \mathrm{CD} 8^{+} \mathrm{T}$-cells revealed that they lacked the receptor for the proinflammatory cytokine IL- 6 and possessed cytotoxic capabilities including the expression of perforin and granzyme $B$ that can contribute to disease pathology [112]. Podolec et al. confirmed reduced frequencies of $T_{N} C D 8^{+} T$-cells in patients with significant narrowing of the coronary arteries compared to individuals with no atherosclerosis [99]. Moreover, proportions of these cells correlated inversely with pulse wave velocity, a measure of arterial stiffness and a predictor of cardiovascular risk, in individuals without atherosclerosis, but not in patients with extensive coronary artery narrowing [99]. The authors suggested that monitoring of this cell subset may be useful during the early stages of coronary atherosclerosis.

Decreased circulating $\mathrm{T}_{\mathrm{N}} \mathrm{CD} 8^{+} \mathrm{T}$-cells have also been reported in patients with ACS compared to individuals with stable CAD [99]. The authors showed that these cells displayed characteristics of immune exhaustion including impaired IL-12 production and upregulation of programmed cell death (PD)-1 molecule, and in vitro experiments indicated that oxLDL may contribute to this phenotype [99]. CD8 ${ }^{+}$T-cells that recognize and respond to oxLDL and HSP60 have been identified in patients with non-ST elevation myocardial infarction or stable angina but not in healthy controls [113]. This suggests that antigen-specific T-cells in atherosclerotic lesions can re-enter the circulation and therefore may be a useful indicator of plaque stability.

\subsection{Treg Cells}

The clinical utility of Treg cells as a metric of atherosclerosis progression has been complicated due to the different cell surface markers used to define these cells. Frequencies of Treg cells identified as $\mathrm{CD} 4^{+} \mathrm{CD} 25^{\text {high }} \mathrm{CD} 127^{\text {low }}$ were found not to be associated with carotid intima-media thickness or progression of atherosclerosis [100]. In contrast, Hasib et al. demonstrated that naive but not memory Treg (defined using the markers CD4, FOXP3, and CD45RA) correlated inversely with right carotid intima-media thickness and also with the presence of atherosclerotic plaques [101].

Using FOXP3 and CD45RA, frequencies of resting and activated Treg cells were reported to be increased in patients with myocardial infarction or stable angina compared to individuals without cardiovascular disease [95]. However, several other investigators found reduced or no differences in the percentages of $\mathrm{CD} 4{ }^{+} \mathrm{CD} 25^{\text {high }} \mathrm{CD} 127^{\text {low }}$ and $\mathrm{CD} 4{ }^{+} \mathrm{CD} 25^{\text {high }} \mathrm{FOXP} 3^{+}$Treg cells in patients with ACS compared to normal controls or patients with stable angina [93,101-105]. Peripheral blood cells from ACS patients cultured in vitro with simvastatin have been shown to increase the number and suppressive function of $\mathrm{CD} 4{ }^{+} \mathrm{CD} 25^{+} \mathrm{FOXP}^{+}$Treg cells, suggesting a beneficial role for statins in stabilizing vulnerable atherosclerosis plaques [114].

\subsection{B-Cells and NKT Cells}

Frequencies of different B-cell subsets including CD19+ B-cells, unswitched (expressing IgM) and switched (expressing IgG or IgA) memory B-cells have been found to be reduced in patients who experienced a secondary cardiovascular event compared to those who did not [106]. A study of 700 individuals followed for 15 years in the Malmo Diet and Cancer Study showed lower baseline percentages of suppressive CD19 ${ }^{+}$B-cells expressing CD40 but higher activated CD19+ B-cells expressing CD86 in individuals with a later incidence of stroke [107]. However, these B-cell subsets were not associated with increased risk of CAD [107]. In patients undergoing percutaneous 
coronary intervention, proportions of iNKT cells were stable during acute myocardial infarction and follow-up [108].

\section{Conclusions}

Compelling evidence implicates adaptive immune cells in all phases of human atherosclerosis, from plaque initiation to destabilization (Figure 2). More extensive studies utilizing plaque tissues are necessary to characterize the effector cells and map critical pathways during atherogenesis. Studies in patients with different stages of atherosclerosis are now providing valuable insight, but heterogeneity of plaque characteristics hampers direct comparison between plaque features and circulating immune cells. Early detection of vulnerable lesions remains the main goal of biomarker discovery. Future studies including circulating cellular biomarkers are warranted to improve identification of vulnerable lesions so that effective intervention can be implemented before clinical manifestations are apparent.

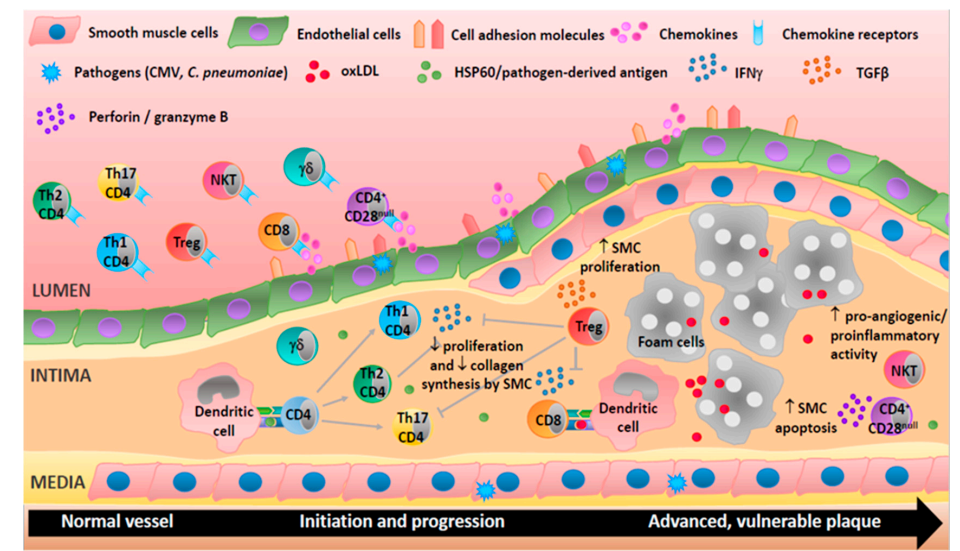

Figure 2. Adaptive immune cells are involved in all stages of human atherosclerosis. Endothelial cells activation upregulates cell adhesion molecules and secretion of chemokines and so directs T-cells to the site of inflammation. T helper (Th) 1 cells produce interferon- $\gamma(\operatorname{IFN} \gamma)$, a proatherogenic cytokine able to activate macrophages, inhibit proliferation, and reduce collagen production by smooth muscle cells. Th2 cells produce interleukin (IL)-4 and may be atheroprotective as they can inhibit Th1 cells. $\mathrm{CD} 4^{+} \mathrm{CD} 28^{\text {null }}$ T-cells may damage cells in the vascular wall via the release of perforin and granzyme $\mathrm{B}$. $\mathrm{CD}^{+}$T-cells may be proatherogenic via the production of IFN $\gamma$ or protective by reducing macrophage content in the plaque. Treg cells can suppress Th1 and Th17 responses and increase smooth muscle cell proliferation through the secretion of cytokines (e.g., transforming growth factor (TGF)- $\beta$ ). Natural killer (NK)T cells exhibit proangiogenic and proinflammatory activities suggesting an involvement in plaque destabilization. Th17 and $\gamma \delta$ T-cells are present in lesions but their roles are not well characterized. T-cells can be activated by heat shock proteins (e.g., HSP60), oxidized lipoproteins (oxLDL), or antigens derived from pathogens (e.g., cytomegalovirus (CMV) and Chlamydia pneumoniae (C. pneumoniae)).

Author Contributions: Writing, S.L.; writing-review and editing, B.B. and G.D. All authors have read and agreed to the published version of the manuscript.

Funding: The preparation of this review article received no external funding.

Acknowledgments: We thank Patricia Price for comments and proofreading of the manuscript.

Conflicts of Interest: Girish Dwivedi has received speaker bureau fees from Amgen and Astra Zeneca not related to this publication. For the remaining authors, there are no conflicts of interest. 


\section{Abbreviations}

\begin{tabular}{|c|c|}
\hline ACS & Acute coronary syndrome \\
\hline BPIFB4 & Bactericidal/permeability-increasing fold-containing family B member 4 \\
\hline CAD & Coronary artery disease \\
\hline CMV & Cytomegalovirus \\
\hline $\mathrm{CV}$ & Cardiovascular \\
\hline DNA & Deoxyribonucleic acid \\
\hline EBV & Epstein-Barr virus \\
\hline FOXP3 & Forkhead box 3 \\
\hline GM-CSF & Granulocyte-macrophage colony-stimulating factor \\
\hline HIV & Human immunodeficiency virus \\
\hline Hs-CRP & High-sensitivity C-reactive protein \\
\hline HSP & Heat shock protein \\
\hline $\mathrm{IFN} \gamma$ & Interferon gamma \\
\hline IL & Interleukin \\
\hline IMT & Intima-media thickness \\
\hline IP-10 & IFN-inducible protein 10 \\
\hline I-TAC & IFN-inducible T-cell $\alpha$ chemoattractant \\
\hline LDL & Low-density lipoproteins \\
\hline LVEF & Left ventricular ejection fraction \\
\hline $\mathrm{MHC}$ & Major histocompatibility complex \\
\hline MI & Myocardial infarction \\
\hline MIG & Monokine induced by IFN $\gamma$ \\
\hline NKT & Natural killer T-cells \\
\hline NSTE & Non-ST elevation \\
\hline oxLDL & Oxidized low-density lipoproteins \\
\hline PBMC & Peripheral blood mononuclear cells \\
\hline PCI & Percutaneous coronary intervention \\
\hline PCR & Polymerase chain reaction \\
\hline PCSK9 & Proprotein convertase subtilisin/kexin type 9 \\
\hline PD-1 & Programmed cell death 1 \\
\hline PWV & Pulse wave velocity \\
\hline RNA & Ribonucleic acid \\
\hline SAP & Stable angina pectoris \\
\hline STE & ST elevation \\
\hline TCR & T-cell receptor \\
\hline TGF $\beta$ & Transforming growth factor beta \\
\hline Th & T helper \\
\hline $\mathrm{TNF} \alpha$ & Tumor necrosis factor alpha \\
\hline Treg & Regulatory T-cells \\
\hline $\mathrm{T}_{\mathrm{CM}}$ & Central memory T-cells \\
\hline $\mathrm{T}_{\mathrm{EM}}$ & Effector memory T-cells \\
\hline $\mathrm{T}_{\mathrm{N}}$ & Naïve T-cells \\
\hline $\mathrm{T}_{\mathrm{TE}}$ & Terminal effector T-cells \\
\hline UA & Unstable angina \\
\hline
\end{tabular}

\section{References}

1. Wong, B.W.; Meredith, A.; Lin, D.; McManus, B.M. The Biological Role of Inflammation in Atherosclerosis. Can. J. Cardiol. 2012, 28, 631-641. [CrossRef]

2. Moore, K.J.; Tabas, I. Macrophages in the Pathogenesis of Atherosclerosis. Cell 2011, 145, 341-355. [CrossRef] [PubMed]

3. Fatkhullina, A.R.; Peshkova, I.O.; Koltsova, E.K. The role of cytokines in the development of atherosclerosis. Biochemistry 2016, 81, 1358-1370. [CrossRef] [PubMed] 
4. Bartlett, B.; Ludewick, H.P.; Misra, A.; Lee, S.; Dwivedi, G. Macrophages and T cells in atherosclerosis: A translational perspective. Am. J. Physiol. Circ. Physiol. 2019, 317, H375-H386. [CrossRef] [PubMed]

5. Farber, D.L.; Yudanin, N.A.; Restifo, N.P. Human memory T cells: Generation, compartmentalization and homeostasis. Nat. Rev. Immunol. 2014, 14, 24-35. [CrossRef] [PubMed]

6. Von Boehmer, H. Mechanisms of suppression by suppressor T cells. Nat. Immunol. 2005, 6, 338-344. [CrossRef] [PubMed]

7. Jonasson, L.; Holm, J.; Skalli, O.; Bondjers, G.; Hansson, G.K. Regional accumulations of T cells, macrophages, and smooth muscle cells in the human atherosclerotic plaque. Arter. Off. J. Am. Heart Assoc. Inc. 1986, 6, 131-138. [CrossRef] [PubMed]

8. Kortelainen, M.-L.; Porvari, K. Adventitial macrophage and lymphocyte accumulation accompanying early stages of human coronary atherogenesis. Cardiovasc. Pathol. 2014, 23, 193-197. [CrossRef]

9. Van Dijk, R.A.; Duinisveld, A.J.F.; Schaapherder, A.F.; Mulder-Stapel, A.; Hamming, J.F.; Kuiper, J.; De Boer, O.J.; Van Der Wal, A.C.; Kolodgie, F.D.; Virmani, R.; et al. A Change in Inflammatory Footprint Precedes Plaque Instability: A Systematic Evaluation of Cellular Aspects of the Adaptive Immune Response in Human Atherosclerosis. J. Am. Heart Assoc. 2015, 4, e001403. [CrossRef]

10. Rohm, I.; Atiskova, Y.; Drobnik, S.; Fritzenwanger, M.; Kretzschmar, D.; Pistulli, R.; Zanow, J.; Krönert, T.; Mall, G.; Figulla, H.R.; et al. Decreased Regulatory T Cells in Vulnerable Atherosclerotic Lesions: Imbalance between Proand Anti-Inflammatory Cells in Atherosclerosis. Mediat. Inflamm. 2015, 2015, 1-13. [CrossRef]

11. De Boer, O.J.; Hirsch, F.; Van Der Wal, A.C.; Van Der Loos, C.M.; Das, P.K.; Becker, A.E. Costimulatory molecules in human atherosclerotic plaques: An indication of antigen specific T lymphocyte activation. Atherosclerosis 1997, 133, 227-234. [CrossRef]

12. Stemme, S.; Holm, J.; Hansson, G.K. T lymphocytes in human atherosclerotic plaques are memory cells expressing CD45RO and the integrin VLA-1. Arter. Thromb. A J. Vasc. Biol. 1992, 12, 206-211. [CrossRef]

13. Zhang, X.; Feng, X.; Cai, W.; Liu, T.; Liang, Z.; Sun, Y.; Yan, C.; Han, Y. Chemokine CX3CL1 and its receptor CX3CR1 are associated with human atherosclerotic lesion volnerability. Thromb. Res. 2015, 135, 1147-1153. [CrossRef] [PubMed]

14. Bonanno, E.; Mauriello, A.; Partenzi, A.; Anemona, L.; Spagnoli, L.G. Flow cytometry analysis of atherosclerotic plaque cells from human carotids: A validation study. Cytometry 2000, 39, 158-165. [CrossRef]

15. Lebedeva, A.; Vorobyeva, D.; Vagida, M.; Ivanova, O.; Felker, E.; Fitzgerald, W.; Danilova, N.; Gontarenko, V.; Shpektor, A.; Vasilieva, E.; et al. Ex vivo culture of human atherosclerotic plaques: A model to study immune cells in atherogenesis. Atherosclerosis 2017, 267, 90-98. [CrossRef] [PubMed]

16. Villa, F.; Carrizzo, A.; Ferrario, A.; Maciag, A.; Cattaneo, M.; Spinelli, C.C.; Montella, F.; Damato, A.; Ciaglia, E.; Puca, A.A. A Model of Evolutionary Selection: The Cardiovascular Protective Function of the Longevity Associated Variant of BPIFB4. Int. J. Mol. Sci. 2018, 19, 3229. [CrossRef] [PubMed]

17. Dossena, M.; Ferrario, A.; Lopardo, V.; Ciaglia, E.; Puca, A.A. New Insights for BPIFB4 in Cardiovascular Therapy. Int. J. Mol. Sci. 2020, 21, 7163. [CrossRef]

18. Ciaglia, E.; Montella, F.; Lopardo, V.; Scala, P.; Ferrario, A.; Cattaneo, M.; Carrizzo, A.; Malovini, A.; Madeddu, P.; Vecchione, C.; et al. Circulating BPIFB4 Levels Associate With and Influence the Abundance of Reparative Monocytes and Macrophages in Long Living Individuals. Front. Immunol. 2020, 11. [CrossRef]

19. Ciaglia, E.; Montella, F.; Maciag, A.; Scala, P.; Ferrario, A.; Banco, C.; Carrizzo, A.; Spinelli, C.C.; Cattaneo, M.; De Candia, P.; et al. Longevity-Associated Variant of BPIFB4 Mitigates Monocyte-Mediated Acquired Immune Response. J. Gerontol. Ser. A Boil. Sci. Med Sci. 2019, 74, S38-S44. [CrossRef]

20. Grivel, J.-C.; Ivanova, O.; Pinegina, N.; Blank, P.S.; Shpektor, A.; Margolis, L.B.; Vasilieva, E. Activation of T Lymphocytes in Atherosclerotic Plaques. Arter. Thromb. Vasc. Biol. 2011, 31, 2929-2937. [CrossRef]

21. Fernandez, D.M.; Rahman, A.H.; Fernandez, N.F.; Chudnovskiy, A.; Amir, E.-A.D.; Amadori, L.; Khan, N.S.; Wong, C.K.; Shamailova, R.; Hill, C.A.; et al. Single-cell immune landscape of human atherosclerotic plaques. Nat. Med. 2019, 25, 1576-1588. [CrossRef] [PubMed]

22. Frostegård, J.; Ulfgren, A.-K.; Nyberg, P.; Hedin, U.; Swedenborg, J.; Andersson, U.; Hansson, G.K. Cytokine expression in advanced human atherosclerotic plaques: Dominance of pro-inflammatory (Th1) and macrophage-stimulating cytokines. Atherosclerosis 1999, 145, 33-43. [CrossRef]

23. De Boer, O.J.; Van Der Wal, A.C.; Verhagen, C.E.; Becker, A.E. Cytokine secretion profiles of cloned T cells from human aortic atherosclerotic plaques. J. Pathol. 1999, 188, 174-179. [CrossRef] 
24. Oliveira, R.T.D.; Silva, R.M.; Teo, F.H.; Mineiro, M.F.; Ferreira, M.C.; Altemani, A.; Mamoni, R.L.; Menezes, F.H.; Blotta, M.H.S.L. Detection of TCD4 ${ }^{+}$subsets in human carotid atheroma. Cytokine 2013, 62, 131-140. [CrossRef] [PubMed]

25. Mach, F.; Sauty, A.; Iarossi, A.S.; Sukhova, G.K.; Neote, K.; Libby, P.; Luster, A.D. Differential expression of three T lymphocyte-activating CXC chemokines by human atheroma-associated cells. J. Clin. Investig. 1999, 104, 1041-1050. [CrossRef]

26. Mallat, Z.; Corbaz, A.; Scoazec, A.; Besnard, S.; Leseèche, G.; Chvatchko, Y.; Tedgui, A. Expression of Interleukin-18 in Human Atherosclerotic Plaques and Relation to Plaque Instability. Circulation 2001, 104, 1598-1603. [CrossRef]

27. Pigarevskii, P.V.; Maltseva, S.V.; Snegova, V.; Davydova, N.G. Role of Interleukin-18 in Destabilization of the Atherosclerotic Plaque in Humans. Bull. Exp. Biol. Med. 2014, 157, 821-824. [CrossRef]

28. Uyemura, K.; Demer, L.L.; Castle, S.C.; Jullien, D.; Berliner, J.A.; Gately, M.K.; Warrier, R.R.; Pham, N.; Fogelman, A.M.; Modlin, R.L. Cross-regulatory roles of interleukin (IL)-12 and IL-10 in atherosclerosis. J. Clin. Investig. 1996, 97, 2130-2138. [CrossRef]

29. Voloshyna, I.; Littlefield, M.J.; Reiss, A.B. Atherosclerosis and interferon-gamma: New insights and therapeutic targets. Trends Cardiovasc. Med. 2014, 24, 45-51. [CrossRef]

30. Eid, R.E.; Rao, D.A.; Zhou, J.; Lo, S.L.; Ranjbaran, H.; Gallo, A.; Sokol, S.I.; Pfau, S.; Pober, J.S.; Tellides, G. Interleukin-17 and interferon-gamma are produced concomitantly by human coronary artery-infiltrating $\mathrm{T}$ cells and act synergistically on vascular smooth muscle cells. Circulation 2009, 119, 1424-1432. [CrossRef]

31. Cheng, X.; Yu, X.; Ding, Y.-J.; Fu, Q.-Q.; Xie, J.-J.; Tang, T.-T.; Yao, R.; Chen, Y.; Liao, Y.-H. The Th17/Treg imbalance in patients with acute coronary syndrome. Clin Immunol. 2008, 127, 89-97. [CrossRef] [PubMed]

32. Hashmi, S.; Zeng, Q.T. Role of interleukin-17 and interleukin-17-induced cytokines interleukin-6 and interleukin-8 in unstable coronary artery disease. Coron. Artery Dis. 2006, 17, 699-706. [CrossRef] [PubMed]

33. Zhang, L.; Wang, T.; Wang, X.Q.; Du, R.Z.; Zhang, K.N.; Liu, X.G.; Ma, D.X.; Yu, S.; Su, G.H.; Li, Z.H.; et al. Elevated frequencies of circulating Th22 cell in addition to Th17 cell and Th17/Th1 cell in patients with acute coronary syndrome. PLoS ONE 2013, 8, e71466. [CrossRef] [PubMed]

34. Liu, Z.; Lu, F.; Pan, H.; Zhao, Y.; Wang, S.; Sun, S.; Li, J.; Hu, X.; Wang, L. Correlation of peripheral Th17 cells and Th17-associated cytokines to the severity of carotid artery plaque and its clinical implication. Atherosclerosis 2012, 221, 232-241. [CrossRef]

35. Liuzzo, G.; Goronzy, J.J.; Yang, H.; Kopecky, S.L.; Holmes, D.R.; Frye, R.L.; Weyand, C.M. Monoclonal T-Cell Proliferation and Plaque Instability in Acute Coronary Syndromes. Circulation 2000, 101, 2883-2888. [CrossRef]

36. Dumitriu, I.E.; Baruah, P.; Finlayson, C.J.; Loftus, I.M.; Antunes, R.F.; Lim, P.; Bunce, N.; Kaski, J.C. High Levels of Costimulatory Receptors OX40 and 4-1BB Characterize CD4 ${ }^{+}$CD28 $8^{\text {null }}$ T Cells in Patients With Acute Coronary Syndrome. Circ. Res. 2012, 110, 857-869. [CrossRef]

37. Dumitriu, I.E. The life (and death) of $\mathrm{CD} 4^{+} \mathrm{CD} 28^{\text {null }} \mathrm{T}$ cells in inflammatory diseases. Immunology 2015, 146, 185-193. [CrossRef]

38. Paul, V.S.V.; Paul, C.M.P.; Kuruvilla, S. Quantification of Various Inflammatory Cells in Advanced Atherosclerotic Plaques. J. Clin. Diagn. Res. 2016, 10, EC35-EC38. [CrossRef]

39. Van Duijn, J.; Kritikou, E.; Benne, N.; Van Der Heijden, T.; Van Puijvelde, G.H.; Kröner, M.J.; Schaftenaar, F.H.; Foks, A.; Wezel, A.; Smeets, H.; et al. CD8 ${ }^{+}$T-cells contribute to lesion stabilization in advanced atherosclerosis by limiting macrophage content and $\mathrm{CD}^{+}{ }^{+}$T-cell responses. Cardiovasc. Res. 2018, 115, 729-738. [CrossRef]

40. Hendel, A.; Cooper, D.; Abraham, T.; Zhao, H.; Allard, M.F.; Granville, D.J. Proteinase inhibitor 9 is reduced in human atherosclerotic lesion development. Cardiovasc. Pathol. 2012, 21, 28-38. [CrossRef]

41. Choy, J.C.; McDonald, P.C.; Suarez, A.C.; Hung, V.H.Y.; Wilson, J.E.; McManus, B.M.; Granville, D.J. Granzyme B in Atherosclerosis and Transplant Vascular Disease: Association with Cell Death and Atherosclerotic Disease Severity. Mod. Pathol. 2003, 16, 460-470. [CrossRef]

42. De Boer, O.J.; Van Der Meer, J.J.; Teeling, P.; Van Der Loos, C.M.; Van Der Wal, A.C. Low Numbers of FOXP3 Positive Regulatory T Cells Are Present in all Developmental Stages of Human Atherosclerotic Lesions. PLoS ONE 2007, 2, e779. [CrossRef]

43. Patel, S.; Chung, S.; White, G.; Bao, S.; Celermajer, D. The "atheroprotective" mediators apolipoproteinA-I and Foxp3 are over-abundant in unstable carotid plaques. Int. J. Cardiol. 2010, 145, 183-187. [CrossRef] [PubMed] 
44. Dietel, B.; Cicha, I.; Voskens, C.J.; Verhoeven, E.; Achenbach, S.; Garlichs, C.D. Decreased numbers of regulatory $\mathrm{T}$ cells are associated with human atherosclerotic lesion vulnerability and inversely correlate with infiltrated mature dendritic cells. Atherosclerosis 2013, 230, 92-99. [CrossRef] [PubMed]

45. Toma, I.; McCaffrey, T.A. Transforming growth factor- $\beta$ and atherosclerosis: Interwoven atherogenic and atheroprotective aspects. Cell Tissue Res. 2012, 347, 155-175. [CrossRef] [PubMed]

46. Foks, A.C.; Lichtman, A.H.; Kuiper, J. Treating Atherosclerosis with Regulatory T Cells. Arter. Thromb. Vasc. Biol. 2015, 35, 280-287. [CrossRef] [PubMed]

47. Ou, H.-X.; Guo, B.-B.; Liu, Q.; Li, Y.-K.; Yang, Z.; Feng, W.-J.; Mo, Z.-C. Regulatory T cells as a new therapeutic target for atherosclerosis. Acta Pharmacol. Sin. 2018, 39, 1249-1258. [CrossRef]

48. Lawand, M.; Déchanet-Merville, J.; Dieu-Nosjean, M.-C. Key Features of Gamma-Delta T-Cell Subsets in Human Diseases and Their Immunotherapeutic Implications. Front. Immunol. 2017, 8, 761. [CrossRef]

49. Vu, D.M.; Tai, A.; Tatro, J.B.; Karas, R.H.; Huber, B.T.; Beasley, D. gammadeltaT cells are prevalent in the proximal aorta and drive nascent atherosclerotic lesion progression and neutrophilia in hypercholesterolemic mice. PLoS ONE 2014, 9, e109416. [CrossRef]

50. Cheng, H.-Y.; Wu, R.; Hedrick, C.C. Gammadelta $(\gamma \delta)$ T lymphocytes do not impact the development of early atherosclerosis. Atherosclerosis 2014, 234, 265-269. [CrossRef]

51. Kleindienst, R.; Xu, Q.; Willeit, J.; Waldenberger, F.R.; Weimann, S.; Wick, G. Immunology of atherosclerosis. Demonstration of heat shock protein 60 expression and $\mathrm{T}$ lymphocytes bearing alpha/beta or gamma/delta receptor in human atherosclerotic lesions. Am. J. Pathol. 1993, 142, 1927-1937. [PubMed]

52. Millonig, G.; Malcom, G.T.; Wick, G. Early inflammato.ry-immunological lesions in juvenile atherosclerosis from the Pathobiological Determinants of Atherosclerosis in Youth (PDAY)-study. Atherosclerosis 2002, 160, 441-448. [CrossRef]

53. Van Puijvelde, G.H.; Kuiper, J. NKT cells in cardiovascular diseases. Eur. J. Pharmacol. 2017, 816, 47-57. [CrossRef] [PubMed]

54. Rombouts, M.; Ammi, R.; Van Brussel, I.; Roth, L.; De Winter, B.Y.; Vercauteren, S.R.; Hendriks, J.M.; Lauwers, P.; Van Schil, P.E.; De Meyer, G.R.Y.; et al. Linking CD11b+ Dendritic Cells and Natural Killer T Cells to Plaque Inflammation in Atherosclerosis. Mediat. Inflamm. 2016, 2016, 1-12. [CrossRef] [PubMed]

55. Bobryshev, Y.V.; Lord, R.S. Co-accumulation of Dendritic Cells and Natural Killer T Cells within Rupture-prone Regions in Human Atherosclerotic Plaques. J. Histochem. Cytochem. 2005, 53, 781-785. [CrossRef] [PubMed]

56. Kyriakakis, E.; Cavallari, M.; Andert, J.; Philippova, M.; Koella, C.; Bochkov, V.; Erne, P.; Wilson, S.B.; Mori, L.; Biedermann, B.C.; et al. Invariant natural killer T cells: Linking inflammation and neovascularization in human atherosclerosis. Eur. J. Immunol. 2010, 40, 3268-3279. [CrossRef] [PubMed]

57. Chan, W.L.; Pejnovic, N.; Hamilton, H.; Liew, T.V.; Popadić, S.; Poggi, A.; Khan, S.M. Atherosclerotic Abdominal Aortic Aneurysm and the Interaction Between Autologous Human Plaque-Derived Vascular Smooth Muscle Cells, Type 1 NKT, and Helper T Cells. Circ. Res. 2005, 96, 675-683. [CrossRef]

58. Huan, T.; Zhang, B.; Wang, Z.; Joehanes, R.; Zhu, J.; Johnson, A.D.; Ying, S.; Munson, P.J.; Raghavachari, N.; Wang, R.; et al. A Systems Biology Framework Identifies Molecular Underpinnings of Coronary Heart Disease. Arter. Thromb. Vasc. Biol. 2013, 33, 1427-1434. [CrossRef]

59. Hamze, M.; Desmetz, C.; Berthe, M.L.; Roger, P.; Boulle, N.; Brancherau, P.; Picard, E.; Guzman, C.; Tolza, C.; Guglielmi, P. Characterization of Resident B Cells of Vascular Walls in Human Atherosclerotic Patients. J. Immunol. 2013, 191, 3006-3016. [CrossRef]

60. De Palma, R.; Del Galdo, F.; Abbate, G.; Chiariello, M.; Calabrò, R.; Forte, L.; Cimmino, G.; Papa, M.F.; Russo, M.G.; Ambrosio, G.; et al. Patients with Acute Coronary Syndrome Show Oligoclonal T-Cell Recruitment Within Unstable Plaque. Circulation 2006, 113, 640-646. [CrossRef]

61. Benagiano, M.; D’Elios, M.M.; Amedei, A.; Azzurri, A.; Van Der Zee, R.; Ciervo, A.; Rombolà, G.; Romagnani, S.; Cassone, A.; Del Prete, G. Human 60-kDa Heat Shock Protein Is a Target Autoantigen of T Cells Derived from Atherosclerotic Plaques. J. Immunol. 2005, 174, 6509-6517. [CrossRef]

62. Rossmann, A.; Henderson, B.; Heidecker, B.; Seiler, R.; Fraedrich, G.; Singh, M.; Parson, W.; Keller, M.; Grubeck-Loebenstein, B.; Wick, G. T-cells from advanced atherosclerotic lesions recognize hHSP60 and have a restricted T-cell receptor repertoire. Exp. Gerontol. 2008, 43, 229-237. [CrossRef]

63. Rahman, M.; Steuer, J.; Gillgren, P.; Hayderi, A.; Liu, A.; Frostegård, J. Induction of Dendritic Cell-Mediated Activation of T Cells From Atherosclerotic Plaques by Human Heat Shock Protein 60. J. Am. Hear. Assoc. 2017, 6, e006778. [CrossRef] [PubMed] 
64. Di Pietro, N.; Formoso, G.; Pandolfi, A. Physiology and pathophysiology of oxLDL uptake by vascular wall cells in atherosclerosis. Vasc. Pharmacol. 2016, 84, 1-7. [CrossRef] [PubMed]

65. Stemme, S.; Faber, B.; Holm, J.; Wiklund, O.; Witztum, J.L.; Hansson, G.K. T lymphocytes from human atherosclerotic plaques recognize oxidized low density lipoprotein. Proc. Natl. Acad. Sci. USA 1995, 92, 3893-3897. [CrossRef] [PubMed]

66. Liu, A.; Frostegård, J. PCSK9 plays a novel immunological role in oxidized LDL-induced dendritic cell maturation and activation of T cells from human blood and atherosclerotic plaque. J. Intern. Med. 2018, 284, 193-210. [CrossRef]

67. Frostegård, J.; Zhang, Y.; Sun, J.; Yan, K.; Liu, A. Oxidized Low-Density Lipoprotein (OxLDL)-Treated Dendritic Cells Promote Activation of T Cells in Human Atherosclerotic Plaque and Blood, Which Is Repressed by Statins: MicroRNA let-7c Is Integral to the Effect. J. Am. Hear. Assoc. 2016, 5, e003976. [CrossRef]

68. Cannon, M.J.; Schmid, D.S.; Hyde, T.B. Review of cytomegalovirus seroprevalence and demographic characteristics associated with infection. Rev. Med Virol. 2010, 20, 202-213. [CrossRef]

69. Lv, Y.; Han, F.-F.; Gong, L.-L.; Liu, H.; Ma, J.; Yu, W.-Y.; Wan, Z.-R.; Jia, Y.-J.; Zhang, W.; Shi, M.; et al. Human cytomegalovirus infection and vascular disease risk: A meta-analysis. Virus Res. 2017, 227, 124-134. [CrossRef]

70. Lichtner, M.; Cicconi, P.; Vita, S.; Cozzi-Lepri, A.; Galli, M.; Caputo, S.L.; Saracino, A.; De Luca, A.; Moioli, M.; Maggiolo, F.; et al. Cytomegalovirus Coinfection Is Associated With an Increased Risk of Severe Non-AIDS-Defining Events in a Large Cohort of HIV-Infected Patients. J. Infect. Dis. 2015, 211, 178-186. [CrossRef]

71. Courivaud, C.; Bamoulid, J.; Chalopin, J.-M.; Gaiffe, E.; Tiberghien, P.; Saas, P.; Ducloux, D. Cytomegalovirus Exposure and Cardiovascular Disease in Kidney Transplant Recipients. J. Infect. Dis. 2013, 207, 1569-1575. [CrossRef] [PubMed]

72. Priyanka, S.; Kaarthikeyan, G.; Nadathur, J.D.; Mohanraj, A.; Kavarthapu, A. Detection of cytomegalovirus, Epstein-Barr virus, and Torque Teno virus in subgingival and atheromatous plaques of cardiac patients with chronic periodontitis. J. Indian Soc. Periodontol. 2017, 21, 456-460. [PubMed]

73. Heybar, H.; Alavi, S.M.; Nejad, M.F.; Latifi, M. Cytomegalovirus Infection and Atherosclerosis in Candidate of Coronary Artery Bypass Graft. Jundishapur J. Microbiol. 2015, 8, e15476. [CrossRef] [PubMed]

74. Cao, J.; Mao, Y.; Dong, B.; Guan, W.; Shi, J.; Wang, S. Detection of specific Chlamydia pneumoniae and cytomegalovirus antigens in human carotid atherosclerotic plaque in a Chinese population. Oncotarget 2017, 8, 55435-55442. [CrossRef] [PubMed]

75. Bayram, A.; Erdoğan, M.B.; Ekşi, F.; Yamak, B. Demonstration of Chlamydophila pneumoniae, Mycoplasma pneumoniae, Cytomegalovirus, and Epstein-Barr virus in atherosclerotic coronary arteries, nonrheumatic calcific aortic and rheumatic stenotic mitral valves by polymerase chain reaction. Anadolu Kardiyol. Dergisi/Anatol. J. Cardiol. 2011, 11, 237-243. [CrossRef] [PubMed]

76. Xenaki, E.; Hassoulas, J.; Apostolakis, S.; Sourvinos, G.; Spandidos, D.A. Detection of Cytomegalovirus in Atherosclerotic Plaques and Nonatherosclerotic Arteries. Angiology 2009, 60, 504-508. [CrossRef]

77. Pampou, S.Y.; Gnedoy, S.N.; Bystrevskaya, V.B.; Smirnov, V.N.; Chazov, E.I.; Melnick, J.L.; DeBakey, M.E. Cytomegalovirus genome and the immediate-early antigen in cells of different layers of human aorta. Virchows Arch. 2000, 436, 539-552. [CrossRef]

78. Yi, L.; Wang, D.-X.; Feng, Z.-J. Detection of Human Cytomegalovirus in Atherosclerotic Carotid Arteries in Humans. J. Formos. Med. Assoc. 2008, 107, 774-781. [CrossRef] 
79. Yaiw, K.-C.; Ovchinnikova, O.; Taher, C.; Mohammad, A.-A.; Davoudi, B.; Shlyakhto, E.V.; Rotar, O.P.; Konradi, A.; Wilhelmi, V.; Rahbar, A.; et al. High prevalence of human cytomegalovirus in carotid atherosclerotic plaques obtained from Russian patients undergoing carotid endarterectomy. Herpesviridae 2013, 4, 3. [CrossRef]

80. Nikitskaya, E.; Lebedeva, A.; Ivanova, O.; Maryukhnich, E.; Shpektor, A.; Grivel, J.; Margolis, L.; Vasilieva, E. Cytomegalovirus-Productive Infection Is Associated With Acute Coronary Syndrome. J. Am. Heart Assoc. 2016, 5, e003759. [CrossRef]

81. Van De Berg, P.J.E.J.; Yong, S.-L.; Remmerswaal, E.B.M.; Van Lier, R.A.W.; Berge, I.J.M.T. Cytomegalovirus-Induced Effector T Cells Cause Endothelial Cell Damage. Clin. Vaccine Immunol. 2012, 19, 772-779. [CrossRef] [PubMed]

82. Sacre, K.; Hunt, P.W.; Hsue, P.Y.; Maidji, E.; Martin, J.N.; Deeks, S.G.; Autran, B.; McCune, J.M. A role for cytomegalovirus-specific $\mathrm{CD} 4^{+} \mathrm{CX} 3 \mathrm{CR} 1^{+} \mathrm{T}$ cells and cytomegalovirus-induced T-cell immunopathology in HIV-associated atherosclerosis. AIDS 2012, 26, 805-814. [CrossRef] [PubMed]

83. Izadi, M.; Fazel, M.; Saadat, S.H.; Naseri, M.H.; Ghasemi, M.; Dabiri, H.; Aryan, R.S.; Esfahani, A.; Ahmadi, A.; Kazemi-Saleh, D.; et al. Cytomegalovirus Localization in Atherosclerotic Plaques Is Associated with Acute Coronary Syndromes: Report Of 105 Patients. Methodist DeBakey Cardiovasc. J. 2012, 8, 42-46. [CrossRef]

84. Liu, R.; Moroi, M.; Yamamoto, M.; Kubota, T.; Ono, T.; Funatsu, A.; Komatsu, H.; Tsuji, T.; Hara, H.; Hara, H.; et al. Presence and Severity of Chlamydia pneumoniae and Cytomegalovirus Infection in Coronary Plaques Are Associated With Acute Coronary Syndromes. Int. Heart J. 2006, 47, 511-519. [CrossRef]

85. De Boer, O.J.; Teeling, P.; Idu, M.M.; Becker, A.E.; Van Der Wal, A.C. Epstein Barr virus specific T-cells generated from unstable human atherosclerotic lesions: Implications for plaque inflammation. Atherosclerosis 2006, 184, 322-329. [CrossRef] [PubMed]

86. Ciszewski, A. Cardioprotective effect of influenza and pneumococcal vaccination in patients with cardiovascular diseases. Vaccine 2018, 36, 202-206. [CrossRef] [PubMed]

87. Keller, T.T.; Van Der Meer, J.J.; Teeling, P.; Van Der Sluijs, K.; Idu, M.M.; Rimmelzwaan, G.F.; Levi, M.; Van Der Wal, A.C.; De Boer, O.J. Selective Expansion of Influenza A Virus-Specific T Cells in Symptomatic Human Carotid Artery Atherosclerotic Plaques. Stroke 2008, 39, 174-179. [CrossRef]

88. Mosorin, M.; Surcel, H.-M.; Laurila, A.; Lehtinen, M.; Karttunen, R.; Juvonen, J.; Paavonen, J.; Morrison, R.P.; Saikku, P.; Juvonen, T. Detection ofChlamydia pneumoniae-Reactive T Lymphocytes in Human Atherosclerotic Plaques of Carotid Artery. Arter. Thromb. Vasc. Biol. 2000, 20, 1061-1067. [CrossRef]

89. De Boer, O.J.; Van Der Wal, A.C.; Houtkamp, M.A.; Ossewaarde, J.M.; Teeling, P.; Becker, A.E. Unstable atherosclerotic plaques contain T-cells that respond to Chlamydia pneumoniae. Cardiovasc. Res. 2000, 48, 402-408. [CrossRef]

90. Nadareishvili, Z.G.; Koziol, D.E.; Szekely, B.; Ruetzler, C.; Labiche, R.; McCarron, R.; DeGraba, T.J. Increased $\mathrm{CD}^{+} \mathrm{T}$ Cells Associated With Chlamydia pneumoniae in Symptomatic Carotid Plaque. Stroke 2001, 32, 1966-1972. [CrossRef]

91. Ammirati, E.; Cianflone, D.; Vecchio, V.; Banfi, M.; Vermi, A.C.; de Metrio, M.; Grigore, L.; Pellegatta, F.; Pirillo, A.; Garlaschelli, K.; et al. Effector Memory T cells Are Associated with Atherosclerosis in Humans and Animal Models. J. Am. Heart Assoc. 2012, 1, 27-41. [CrossRef] [PubMed]

92. Moro-García, M.A.; Iglesias, F.L.; Avanzas, P.; Echeverría, A.; López-Larrea, C.; de la Tassa, C.M.; Alonso-Arias, R. Disease complexity in acute coronary syndrome is related to the patient's immunological status. Int. J. Cardiol. 2015, 189, 115-123. [CrossRef] [PubMed]

93. Zhao, Z.; Wu, Y.; Cheng, M.; Ji, Y.; Yang, X.; Liu, P.; Jia, S.; Yuan, Z.-Y. Activation of Th17/Th1 and Th1, but not Th17, is associated with the acute cardiac event in patients with acute coronary syndrome. Atherosclerosis 2011, 217, 518-524. [CrossRef] [PubMed]

94. Li, C.; Zong, W.; Zhang, M.; Tu, Y.; Zhou, Q.; Ni, M.; Li, Z.; Liu, H.; Zhang, J. Increased Ratio of Circulating T-Helper 1 to T-Helper 2 Cells and Severity of Coronary Artery Disease in Patients with Acute Myocardial Infarction: A Prospective Observational Study. Med. Sci. Monit. 2019, 25, 6034-6042. [CrossRef]

95. Emoto, T.; Sasaki, N.; Yamashita, T.; Kasahara, K.; Yodoi, K.; Sasaki, Y.; Matsumoto, T.; Mizoguchi, T.; Hirata, K.-I. Regulatory/effector T-cell ratio is reduced in coronary artery disease. Circ. J. 2014, 78, 2935-2941. [CrossRef] 
96. Bergstrom, I.; Backteman, K.; Lundberg, A.; Ernerudh, J.; Jonasson, L. Persistent accumulation of interferon-gamma-producing $\mathrm{CD} 8{ }^{+} \mathrm{CD} 56^{+} \mathrm{T}$ cells in blood from patients with coronary artery disease. Atherosclerosis 2012, 224, 515-520. [CrossRef]

97. Kolbus, D.; Ljungcrantz, I.; Andersson, L.; Hedblad, B.; Fredrikson, G.N.; Björkbacka, H.; Nilsson, J. Association between $\mathrm{CD}^{+}$T-cell subsets and cardiovascular disease. J. Intern. Med. 2013, 274, 41-51. [CrossRef]

98. Zidar, D.A.; Mudd, J.C.; Juchnowski, S.; Lopes, J.P.; Sparks, S.; Park, S.S.; Ishikawa, M.; Osborne, R.; Washam, J.B.; Chan, C.; et al. Altered Maturation Status and Possible Immune Exhaustion of CD8 $\mathrm{T}$ Lymphocytes in the Peripheral Blood of Patients Presenting With Acute Coronary Syndromes. Arter. Thromb. Vasc. Biol. 2016, 36, 389-397. [CrossRef]

99. Podolec, J.; Niewiara, L.; Skiba, D.S.; Siedlinski, M.; Baran, J.; Komar, M.; Guzik, B.; Kablak-Ziembicka, A.; Kopeć, G.; Guzik, T.; et al. Higher levels of circulating naïve CD8 ${ }^{+} \mathrm{CD} 45 \mathrm{RA}{ }^{+}$cells are associated with lower extent of coronary atherosclerosis and vascular dysfunction. Int. J. Cardiol. 2018, 259, 26-30. [CrossRef]

100. Ammirati, E.; Cianflone, D.; Banfi, M.; Vecchio, V.; Palini, A.; De Metrio, M.; Marenzi, G.; Panciroli, C.; Tumminello, G.; Anzuini, A.; et al. Circulating CD4 + CD25 hi CD127 lo Regulatory T-Cell Levels Do Not Reflect the Extent or Severity of Carotid and Coronary Atherosclerosis. Arter. Thromb. Vasc. Biol. 2010, 30, 1832-1841. [CrossRef]

101. Hasib, L.; Lundberg, A.K.; Zachrisson, H.; Ernerudh, J.; Jonasson, L. Functional and homeostatic defects of regulatory $\mathrm{T}$ cells in patients with coronary artery disease. J. Intern. Med. 2015, 279, 63-77. [CrossRef] [PubMed]

102. Liu, M.; Xu, L.-J.; Wu, J.-X. Changes of circulating $\mathrm{CD} 4{ }^{+} \mathrm{CD} 25^{+} \mathrm{CD} 127^{\text {low }}$ regulatory T cells in patients with acute coronary syndrome and its significance. Genet. Mol. Res. 2015, 14, 15930-15936. [CrossRef] [PubMed]

103. Potekhina, A.V.; Pylaeva, E.; Provatorov, S.; Ruleva, N.; Masenko, V.; Noeva, E.; Krasnikova, T.; Arefieva, T. Treg/Th17 balance in stable CAD patients with different stages of coronary atherosclerosis. Atherosclerosis 2015, 238, 17-21. [CrossRef] [PubMed]

104. Huang, L.; Zheng, Y.; Yuan, X.; Ma, Y.; Xie, G.; Wang, W.; Chen, H.; Shen, L. Decreased frequencies and impaired functions of the CD31+subpopulation in Tregcells associated with decreased FoxP3 expression and enhanced Tregcell defects in patients with coronary heart disease. Clin. Exp. Immunol. 2016, 187, 441-454. [CrossRef]

105. Backteman, K.; Andersson, C.; Dahlin, L.-G.; Ernerudh, J.; Jonasson, L. Lymphocyte Subpopulations in Lymph Nodes and Peripheral Blood: A Comparison between Patients with Stable Angina and Acute Coronary Syndrome. PLoS ONE 2012, 7, e32691. [CrossRef]

106. Meeuwsen, J.A.L.; Van Duijvenvoorde, A.; Gohar, A.; Kozma, M.O.; Van De Weg, S.M.; Gijsberts, C.M.; Haitjema, S.; Björkbacka, H.; Fredrikson, G.N.; De Borst, G.J.; et al. High Levels of (Un)Switched Memory B Cells Are Associated With Better Outcome in Patients With Advanced Atherosclerotic Disease. J. Am. Heart Assoc. 2017, 6. [CrossRef]

107. Mantani, P.T.; Ljungcrantz, I.; Andersson, L.; Alm, R.; Hedblad, B.; Björkbacka, H.; Nilsson, J.-Å.; Fredrikson, G.N. Circulating CD40 + and CD86 + B Cell Subsets Demonstrate Opposing Associations With Risk of Stroke. Arter. Thromb. Vasc. Biol. 2014, 34, 211-218. [CrossRef]

108. Novak, J.; Dobrovolny, J.; Tousek, P.; Kočka, V.; Teringova, E.; Nováková, L.; Widimský, P. Potential role of invariant natural killer T cells in outcomes of acute myocardial infarction. Int. J. Cardiol. 2015, 187, 663-665. [CrossRef]

109. Pera, A.; Caserta, S.; Albanese, F.; Blowers, P.; Morrow, G.; Terrazzini, N.; Smith, H.E.; Rajkumar, C.; Reus, B.; Msonda, J.R.; et al. CD28 ${ }^{\text {null }}$ pro-atherogenic CD4 T-cells explain the link between CMV infection and an increased risk of cardiovascular death. Theranostics 2018, 8, 4509-4519. [CrossRef]

110. Athanassopoulos, P.; Vaessen, L.M.B.; Balk, A.H.M.M.; Weimar, W.; Sharma, H.S.; Bogers, A.J.J.C. Altered Chemokine Receptor Profile on Circulating Leukocytes in Human Heart Failure. Cell Biophys. 2006, 44, 083-102. [CrossRef]

111. Kyaw, T.; Tipping, P.; Toh, B.-H.; Bobik, A. Killer cells in atherosclerosis. Eur. J. Pharmacol. 2017, 816, 67-75. [CrossRef] [PubMed]

112. Hwang, Y.; Yu, H.T.; Kim, N.-H.; Jang, J.; Kim, H.Y.; Kang, I.; Kim, H.C.; Park, S.; Lee, W.-W. Expansion of $\mathrm{CD}^{+} \mathrm{T}$ cells lacking the IL-6 receptor $\alpha$ chain in patients with coronary artery diseases (CAD). Atherosclerosis 2016, 249, 44-51. [CrossRef] [PubMed] 
113. Ghio, M.; Fabbi, P.; Contini, P.; Fedele, M.; Brunelli, C.; Indiveri, F.; Barsotti, A. OxLDL- and HSP-60 antigen-specific $\mathrm{CD}^{+} \mathrm{T}$ lymphocytes are detectable in the peripheral blood of patients suffering from coronary artery disease. Clin. Exp. Med. 2013, 13, 251-255. [CrossRef] [PubMed]

114. Meng, X.; Zhang, K.; Li, J.; Dong, M.; Yang, J.; An, G.; Qin, W.; Gao, F.; Zhang, C.; Zhang, Y. Statins Induce the Accumulation of Regulatory T Cells in Atherosclerotic Plaque. Mol. Med. 2012, 18, 598-605. [CrossRef]

Publisher's Note: MDPI stays neutral with regard to jurisdictional claims in published maps and institutional affiliations.

(C) 2020 by the authors. Licensee MDPI, Basel, Switzerland. This article is an open access article distributed under the terms and conditions of the Creative Commons Attribution (CC BY) license (http://creativecommons.org/licenses/by/4.0/). 